Aldo Clerico, Fabio A. Recchia, Claudio Passino and Michele Emdin

Am J Physiol Heart Circ Physiol 290:17-29, 2006. doi:10.1152/ajpheart.00684.2005

You might find this additional information useful...

This article cites 192 articles, 63 of which you can access free at:

http://ajpheart.physiology.org/cgi/content/full/290/1/H17\#BIBL

This article has been cited by 9 other HighWire hosted articles, the first 5 are:

Predictive Value of Brain Natriuretic Peptides in Patients on Peritoneal Dialysis: Results from the ADEMEX Trial

R. Paniagua, D. Amato, S. Mujais, E. Vonesh, A. Ramos, R. Correa-Rotter and W. H. Horl

Clin. J. Am. Soc. Nephrol., March 1, 2008; 3 (2): 407-415.

[Abstract] [Full Text] [PDF]

Influence of ScaI and Natriuretic Peptide (NP) Clearance Receptor Polymorphisms of the NP System on NP Concentration in Chronic Heart Failure

C. Vassalle, M. G. Andreassi, C. Prontera, M. Fontana, L. Zyw, C. Passino and M. Emdin

Clin. Chem., November 1, 2007; 53 (11): 1886-1890.

[Abstract] [Full Text] [PDF]

Comparison of Brain Natriuretic Peptide (BNP) and Amino-Terminal ProBNP for Early Diagnosis of Heart Failure

M. Emdin, C. Passino, C. Prontera, M. Fontana, R. Poletti, A. Gabutti, C. Mammini, A.

Giannoni, L. Zyw, G. Zucchelli and A. Clerico

Clin. Chem., July 1, 2007; 53 (7): 1289-1297.

[Abstract] [Full Text] [PDF]

\author{
Independent Components of Chronic Kidney Disease as a Cardiovascular Risk State: \\ Results From the Kidney Early Evaluation Program (KEEP) \\ P. A. McCullough, C. T. Jurkovitz, P. E. Pergola, J. B. McGill, W. W. Brown, A. J. Collins, \\ S.-C. Chen, S. Li, A. Singh, K. C. Norris, M. J. Klag, G. L. Bakris and for the KEEP \\ Investigators \\ Arch Intern Med, June 11, 2007; 167 (11): 1122-1129. \\ [Abstract] [Full Text] [PDF] \\ Comparison of the Diagnostic Accuracy of Brain Natriuretic Peptide (BNP) and the \\ N-Terminal Part of the Propeptide of BNP Immunoassays in Chronic and Acute Heart \\ Failure: A Systematic Review \\ A. Clerico, M. Fontana, L. Zyw, C. Passino and M. Emdin \\ Clin. Chem., May 1, 2007; 53 (5): 813-822. \\ [Abstract] [Full Text] [PDF]
}

Medline items on this article's topics can be found at http://highwire.stanford.edu/lists/artbytopic.dtl on the following topics:

Biochemistry .. Brain Natriuretic Peptide

Biochemistry .. Natriuretic Peptide

Medicine .. Cardiovascular Diseases

Pharmacology .. Heart Diseases (Drug Development)

Physiology .. Contractility

Physiology .. Homeostasis

Updated information and services including high-resolution figures, can be found at:

http://ajpheart.physiology.org/cgi/content/full/290/1/H17

Additional material and information about AJP - Heart and Circulatory Physiology can be found at: http://www.the-aps.org/publications/ajpheart

This information is current as of March 18, 2008.

AJP - Heart and Circulatory Physiology publishes original investigations on the physiology of the heart, blood vessels, and lymphatics, including experimental and theoretical studies of cardiovascular function at all levels of organization ranging from the intact animal to the cellular, subcellular, and molecular levels. It is published 12 times a year (monthly) by the American

Physiological Society, 9650 Rockville Pike, Bethesda MD 20814-3991. Copyright (C) 2005 by the American Physiological Society. ISSN: 0363-6135, ESSN: 1522-1539. Visit our website at http://www.the-aps.org/. 


\title{
Cardiac endocrine function is an essential component of the homeostatic regulation network: physiological and clinical implications
}

\author{
Aldo Clerico, ${ }^{1}$ Fabio A. Recchia, ${ }^{2,3}$ Claudio Passino, ${ }^{1}$ and Michele Emdin ${ }^{1}$ \\ ${ }^{1}$ Consiglio Nazionale delle Ricerca Institute of Clinical Physiology and ${ }^{2}$ Scuola Superiore \\ Sant'Anna, Pisa, Italy; and ${ }^{3}$ New York Medical College, Valhalla, New York
}

\begin{abstract}
Clerico, Aldo, Fabio A. Recchia, Claudio Passino, and Michele Emdin. Cardiac endocrine function is an essential component of the homeostatic regulation network: physiological and clinical implications. Am J Physiol Heart Circ Physiol 290: H17-H29, 2006; doi:10.1152/ajpheart.00684.2005.- The discovery of cardiac natriuretic hormones required a profound revision of the concept of heart function. The heart should no longer be considered only as a pump but rather as a multifunctional and interactive organ that is part of a complex network and active component of the integrated systems of the body. In this review, we first consider the cross-talk between endocrine and contractile function of the heart. Then, based on the existing literature, we propose the hypothesis that cardiac endocrine function is an essential component of the integrated systems of the body and thus plays a pivotal role in fluid, electrolyte, and hemodynamic homeostasis. We highlight those studies indicating how alterations in cardiac endocrine function can better explain the pathophysiology of cardiovascular diseases and, in particular of heart failure, in which several target organs develop a resistance to the biological action of cardiac natriuretic peptides. Finally, we emphasize the concept that a complete knowledge of the cardiac endocrine function and of its relation with other neurohormonal regulatory systems of the body is crucial to correctly interpret changes in circulating natriuretic hormones, especially the brain natriuretic peptide.
\end{abstract}

atrial natriuretic peptide; brain natriuretic peptide; cardiac natriuretic hormones; cardiac function; heart failure; cardiovascular diseases

THE PRESENCE OF SECRETORY GRANULES in mammalian (including human) atrial cells has been known since 1965 (66, 77), but only in 1976 did Marie et al. (102) find that the formation of these granules could be influenced by changes in the hydroelectrolytic balance. From those original observations, De Bold et al. (29) demonstrated in 1981 that intravenous injection of atrial extracts provoked a rapid and massive diuresis and natriuresis in rats.

This seminal study paved the way for the isolation, purification, and identification of a family of natriuretic and vasodilator peptides named atrial natriuretic peptides or factors and more commonly known as $\operatorname{ANP}$ or $\operatorname{ANF}(20,30,33,105,136)$. Furthermore, it was demonstrated that not only atrial, but also ventricular, cardiomyocytes can secrete peptides with natriuretic activity, in particular, the brain natriuretic peptide (BNP), so called because first isolated from porcine brain (20, 30, 33, 105, 136). More recently, C-type natriuretic peptide (CNP), mainly produced and secreted by endothelial cells and by central nervous system neurons, and urodilatin, synthesized and secreted by renal cells (and present in urine, but not in plasma), were added to this peptide family $(20,30,33,105$, 136). Finally, a new peptide, named dendroaspis natriuretic peptide (DNP), was identified in mammalian plasma, but itsorigin and pathophysiological relevance are still unclear (132).

Address for reprint requests and other correspondence: A. Clerico, Laboratory of Cardiovascular Endocrinology and Cell Biology, CNR Institute of Clinical Physiology, Via Trieste 41, 56126 Pisa, Italy (email: clerico@ifc.cnr.it).
The scientific impact of these studies was of paramount importance. The discovery of cardiac natriuretic hormones (CNH) by De Bold et al. (29) made it necessary, 25 years later, to completely revise the concept of heart function. Indeed, we should no longer consider the heart only as a pump but rather as a multifunctional and interactive organ, a nodal point in a complex network, and an active component of the integrated systems of the body (including nervous, endocrine, and immune system). It is now clear that the heart exerts also an endocrine function, plays a key role in the regulation of circulation, and hydroelectrolytic homeostasis, and can exchange physiologically relevant information with other organs and systems, which include central and autonomic nervous system, kidney, adrenal glands, vascular endothelium, adipose tissue, and immune system $(30,105)$. This previously unsuspected cardiac function explains the great pathophysiological and clinical significance that a rapidly growing number of studies is attributing to natriuretic peptides (20). Indeed, cardiac endocrine function should be considered closely related and integrated with other cardiomyocyte properties, such as excitability and contractility. Moreover, this function can be evaluated and measured with methodological approaches and laboratory techniques commonly used for studying and measuring the activity of endocrine glands. Finally, the results of these investigations need to be interpreted in light of classic endocrinological concepts, such as hormone production, metabolism, peripheral action, and specific receptors.

In the this review, we will consider a number of studies supporting the hypothesis that an important exchange of infor- 
H18 CARDIAC ENDOCRINE FUNCTION
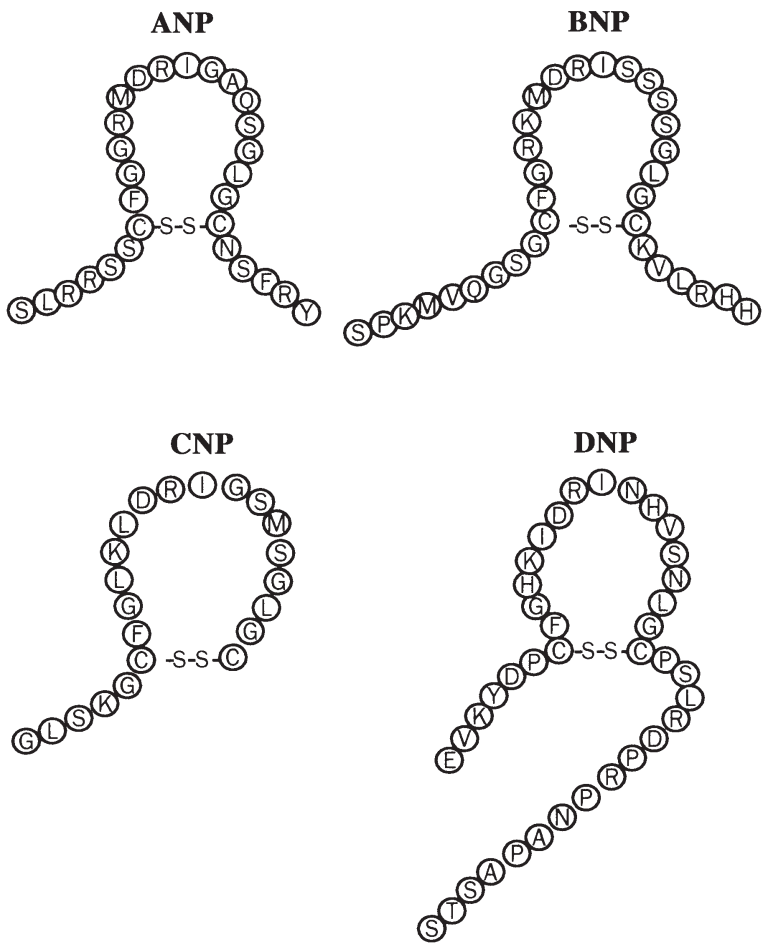

Fig. 1. Peptide chains of the atrial natriuretic peptide (ANP), brain natriuretic peptide (BNP), C-type natriuretic peptide (CNP), and dendroaspis natriuretic peptide (DNP).

mation exists between endocrine and contractile function of the heart. In our opinion, understanding this integration may lead to a more accurate and complete comprehension of cardiac physiology and of the pathophysiology of heart failure. Furthermore, we will discuss a second intriguing hypothesis, i.e., that cardiac endocrine function is an essential component of the integrated systems of the body and thus plays a pivotal role in fluid, electrolyte, and hemodynamic homeostasis. Whereas previous reviews have extensively covered the topic of cardiac hormones, they have not sufficiently emphasized the cross-talk between cardiac endocrine and contractile function and between cardiac endocrine function and other integrated systems of the body. Moreover, the pathophysiological and clinical relevance of these interactions currently have not been discussed in detail. On the basis of such premises, we will first discuss those studies supporting the hypothesis that cardiac endocrine function can better explain some pathophysiological mechanisms acting in myocardial dysfunction, heart failure, and other cardiovascular diseases. Emphasis will be put on the strong and pathophysiologically relevant effects of cardiac natriuretic peptides on peripheral resistance in heart failure. Finally, we will try to provide arguments to support the idea that a complete knowledge of the cardiac endocrine system and of its relations with other neurohormonal regulatory systems of the organism is crucial to interpret correctly measurements of $\mathrm{CNH}$ and in particular of BNP.

\section{CHEMICAL STRUCTURE AND SYNTHESIS OF CNH}

All CNH share a similar structural conformation, characterized by a peptide ring with a cysteine bridge. This ring remained well preserved throughout the phylogenetic evolu- tion, because it constitutes the site of the peptidic hormone that binds to its specific receptor. Conversely, the two-terminal amino acid chains (i.e., $\mathrm{NH}_{2}$ and $\mathrm{COOH}$ terminus) show a high degree of variability among the natriuretic peptides in terms of both length and composition (Fig. 1).

The natriuretic peptide genes encode for the precursor sequences of these hormones, named preprohormones, which are then splitted into prohormones by proteolytic cleavage of a $\mathrm{NH}_{2}$-terminal hydrophobic signal peptide. This cleavage occurs cotranslationally during protein synthesis in the rough endoplasmic reticulum before the synthesis of the $\mathrm{COOH}$ terminal part of the prohormone sequence is completed (49). In particular, the human BNP gene encodes for a preproBNP molecule of 134 amino acid residues, including a signal peptide of 26 amino acids (Fig. 2). BNP is cleaved out of a prohormone molecule of 108 amino acids, the proBNP $1-108$, usually indicated as proBNP. Before secretion, proBNP is split by proteolytic enzymes into two peptides: the proBNP ${ }_{1-76}$ ( $\mathrm{NH}_{2}$-terminal peptide fragment), usually indicated as NTproBNP and biologically inactive, and the proBNP ${ }_{77-108}$ (COOH-terminal peptide fragment), which is the active hormone (BNP).

It is important to note that the preproBNP precursor is not detectable, and its existence is only theoretically deduced from the BNP cDNA sequence of human (or other mammalian) gene. On the other hand, intact proBNP, NT-proBNP, and BNP are identifiable in plasma by chromatography and immunoassay $(8,49,146,147)$. Moreover, ANP and BNP can be produced and costored in the same granule in different stages of peptide maturation $(30,105)$.

\section{REGULATION OF PRODUCTION/SECRETION OF ANP AND BNP IN CARDIAC TISSUE}

ANP and BNP are synthesized and secreted mainly by cardiomyocytes. However, it is believed that ANP is preferentially produced in the atria, whereas BNP is preferentially synthesized in the ventricles and particularly in patients with chronic cardiac diseases. Synthesis and secretion of those two peptides may be differently regulated in atrial versus ventric-

\section{CARDIOMYOCYTE}

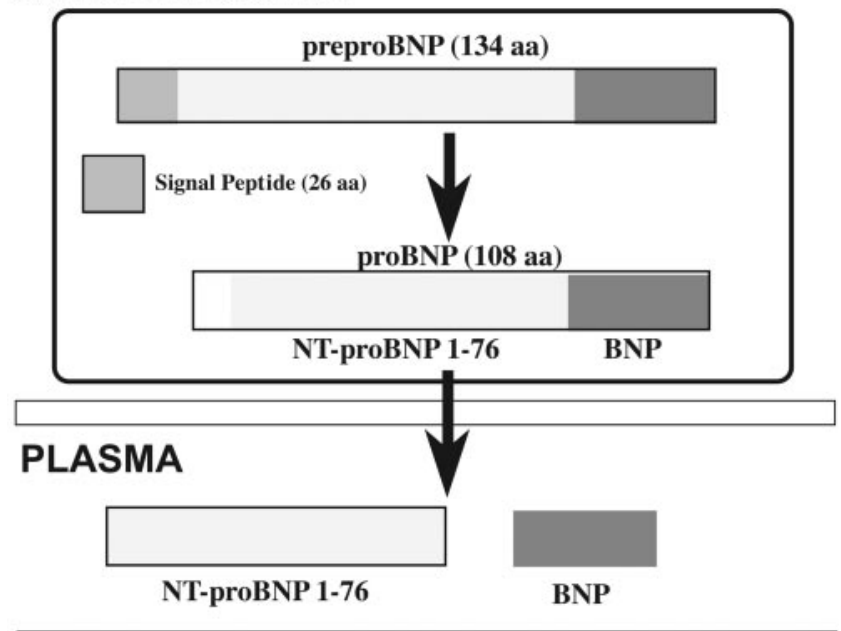

Fig. 2. Schematic representation of production/secretion pathways of BNP and of its precursor peptides. 
ular myocytes and, probably, during neonatal versus adult life $(30,31,105)$. As a consequence, it is conceivable that two separate cardiac endocrine systems exist, i.e., one in the atrium, where ANP and its related peptides are preferentially produced, and the other in the ventricle, prevalently secreting BNP and its related peptides. Therefore, the acronym $\mathrm{CNH}$ will be used in this review only when it is clear that all natriuretic peptides share the same features and actions in a given context. Otherwise, ANP and BNP will be discussed as separate hormones.

It is important to note that more information is available about the mechanisms responsible for the regulation of production/secretion of ANP in atrial cardiomyocytes rather than BNP in ventricular cardiomyocytes. Furthermore, these data were obtained from experimental animals, especially rodents and, to a lesser extent, pigs and sheep. However, some evidence suggests prudence in their use for the interpretation of specific pathophysiological conditions in humans. On the other hand, BNP and its related peptides have been preferentially used for diagnosis, stratification, and monitoring of patients with cardiac and noncardiac diseases during the most recent years, thus more clinical data are available on these peptides than on ANP and its related peptides.

It is likely that most of the circulating ANP and BNP derive from the atria in healthy subjects (105). Some recent data suggested that not only cardiomyocites, but also fibroblasts, may produce $\mathrm{CNH}$ in the human heart (169). It has also been proposed that the endocrine response of the heart to pressure or volume load varies depending on whether the stimulus is acute, subacute, or chronic $(30,105)$.

Atrial cardiomyocytes store prohormones (proANP and proBNP) in secretory granules and split them into ANP and BNP before secretion. Consequently, cardiac natriuretic hormones seem predominantly secreted throughout a regulated pathway $(30,31,105)$. However, there is also the possibility that some ANP is constitutively released by passive diffusion (30, 31, 105). BNP gene is expressed in both atrial and ventricular myocytes of normal and diseased hearts (30, 31, 105, 136).

Ventricular myocytes do not usually display any evident secretory granules at electron microscopy in the normal heart of adult mammals (105). However, some authors identified secretory granules, similar to the atrial ones, in samples of ventricular myocardium collected during surgery or in endocardial biopsies studied by electron microscopy and immunohistocytochemistry $(57,115)$. These observations suggest that normal ventricular myocardium may produce only a limited amount of BNP in response to an acute and efficacious stimulation, probably via a constitutive secretory pathway, whereas the amount of hormone produced and secreted after chronic stimulation could be greatly increased via a secretory pathway that is upregulated in patients with cardiac disease (105).

From a clinical point of view, it is important to note that chronic cardiac dysfunction induces the secretion of a greater amount of BNP rather than ANP, probably because the former is produced mainly by ventricular myocardium, of which its mass is predominant. Moreover, ventricular BNP gene expression can be selectively upregulated during the evolution of diseases affecting the ventricles, as demonstrated experimentally in dogs with pacing-induced congestive heart failure (94). Consistent with these experimental findings, the molar ratio of circulating BNP over ANP increases progressively with the severity of heart failure from a mean value of 0.5 in healthy subjects up to 3 in patients with New York Heart Association (NYHA) functional class IV (Table 1) (20). These data explain why circulating BNP is a better diagnostic index in patients with cardiac disease compared with $\operatorname{ANP}(20,22)$.

\section{MECHANICAL AND CHEMICAL STIMULI}

Wall stretch is the most important stimulus for synthesis and secretion of ANP in the atrial walls (30, 31, 105, 136, 145, 152). For this reason, any physiological condition associated with an acute increase in venous return (preload), such as physical exercise, rapid changes from standing to supine position, and head-out water immersion, causes a more rapid augmentation in ANP than in BNP plasma concentration in an adult healthy subject. For instance, changes in ANP and BNP secretion have been well characterized during and after tachyarrhythmia induced in pigs by rapid atrial pacing (225 impulses/ min). In this model, ANP plasma concentration shows a sharp initial peak followed by a decline but remains significantly elevated throughout the 24-h postpacing, whereas BNP increases significantly after an 8 -h pacing period and even more after a 24-h pacing (129). Also acute changes in the effective plasma circulating volume, for instance, during a dialysis session in patients with chronic renal failure, cause greater variations in circulating levels of ANP than BNP (20).

Wall distension is generally considered the main mechanical stimulus also for BNP production by ventricular tissue. This occurs in conditions characterized by electrolyte and fluid retention, and therefore expansion of effective plasma volume, such as primary or secondary hyperaldosteronism accompanying cardiac, renal, and liver failure (20, 30, 105). However, several studies indicate that BNP production/secretion may be differently regulated in normal compared with diseased ventricular myocardium. Indeed, ventricular hypertrophy and especially the concomitant presence of fibrosis can stimulate

Table 1. BNP and ANP and molar ratio (BNP/ANP) value in normal subjects and patients with heart failure divided according to NYHA functional class

\begin{tabular}{|c|c|c|c|c|c|}
\hline & $\begin{array}{l}\text { Normal } \\
\text { Subjects }\end{array}$ & NYHA I & NYHA II & NYHA III & NYHA IV \\
\hline$n$ & 52 & 35 & 141 & 97 & 39 \\
\hline BNP & $4.1 \pm 6.1$ & $22.5 \pm 34.0$ & $66.6 \pm 88.4$ & $131.6 \pm 126.3$ & $185.7 \pm 169.2$ \\
\hline Molar ratio & 0.5 & 1.2 & 1.8 & 2.0 & 3.0 \\
\hline
\end{tabular}

Values are means $\pm \mathrm{SD}$ in pmol/l; $n$, number of subjects. BNP, brain natriuretic peptide; ANP atrial natriuretic peptide; NYHA, New York Heart Association. Unpublished data from the authors' laboratory. 
BNP production $(30,31,105,141,156,181)$. Furthermore, more recently, experimental and clinical studies indicated that also myocardial ischemia, and perhaps hypoxia, per se, could induce the synthesis/secretion of BNP and its related peptides by ventricular cells, even if isolated and cultured $(7,32,49,52$, 68,165 ). Plasma levels of $\mathrm{CNH}$, especially BNP and its related peptides, were found closely related to aerobic exercise capacity in patients with heart failure $(76,186,189)$. In particular, plasma NT-proBNP correlates better with peak oxygen consumption and exercise duration compared with other indexes of left ventricular systolic function, such as ejection fraction (186). These results may explain the elevated levels of BNP found in patients with acute coronary syndrome or during exercise-induced ischemia $(43,138)$, in the absence of a significant dilatation of ventricular chambers $(7,32)$, suggesting a neurohormonal activation secondary to both reversible myocardial ischemia or necrosis (68).

\section{HUMORAL STIMULI}

Mounting evidence from in vivo and ex vivo studies is providing support to the hypothesis that the production/secretion of ANP and BNP is regulated by complex interactions with the neurohormonal and immune systems, especially in the ventricular myocardium (105). A summary list of some neurohormones, cytokines, and growth factors, which can affect the production/secretion of ANP and BNP, is reported in Table 2.

Endothelin-1 and angiotensin II are considered the most powerful stimulators of production/secretion of both ANP and BNP (30, 31, 105); similarly, glucocorticoids, sex steroid hormones, thyroid hormones, some growth factors, and cytokines (especially TNF- $\alpha$, interleukin-1, and interleukin-6) share stimulating effects on the CNH system $(30,31,35,54$, $61,85,95,97,105,156,160,187,188)$. The finding that $\mathrm{CNH}$ production is stimulated by cytokines and growth factors suggests a link between cardiac endocrine activity and remodeling or inflammatory processes in myocardial and smooth muscle cells. A large number of studies have recently contributed to support this hypothesis $(35,48,55,59,61,76,78,95,141,151$, $156,160,181,187,188)$.

More complex, and still in part unknown, is the effect of adrenergic stimulation on $\mathrm{CNH}$ production. The $\alpha_{1}$-adrenergic agonist phenylephrine enhances the expression of some transcription factors, such as Egr-l and c-myc, which regulate (usually increasing) natriuretic peptide gene expression in cultured neonatal rat cardiomyocytes $(30,31,74,78,105,151$,

Table 2. Summary list of some neurohormones, cytokines, and growth factors affecting the production/secretion of $\mathrm{CNH}$

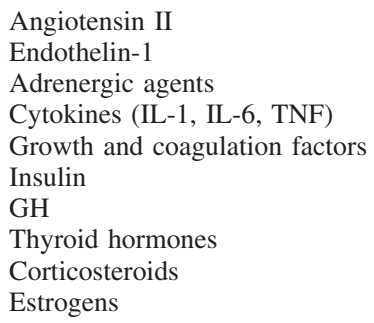

$\mathrm{CNH}$, cardiac natriuretic hormone; $\mathrm{GH}$, growth hormone.
162). In isolated adult mouse cardiomyocytes, the $\beta$-agonist isoproterenol reduced the expression of BNP mRNA but not of ANP, an effect that was prevented by the $\beta_{1}$-antagonist CGP20712A (4). Clinical studies performed in hypertensive patients have shown that monotherapy with $\beta$-blockers, either $\beta_{1}$-selective or not, is associated with an increase in the plasma concentration of ANP and/or BNP and their related peptides $(53,114,123,171)$. In contrast, the CNH response can be heterogeneous during $\beta$-blocker therapy in congestive heart failure $(22,192)$ probably due to the various additive effects of other coadministered drugs. Nevertheless, a chronic treatment with $\beta$-blockers, resulting in improvement of cardiac function and exercise capacity and reduction in filling pressure and cardiac volumes, is usually associated with a significant fall in BNP and its related peptides in patients with heart failure (22, 44, 157).

As far as hormones more specifically acting on intermediate metabolism are concerned, insulin, but not hyperglycemia alone, increased ANP expression and secretion in cultured rat cardiac myocytes (163). Moreover, in a model of genetic murine dilated cardiomyopathy, short-term treatment with the growth hormone releasing factor improved left ventricular function and significantly limited ANP and BNP gene overexpression in left ventricular tissue (63).

In summary, a conspicuous number of experimental and clinical studies demonstrated that production and secretion of $\mathrm{CNH}$ are closely and subtly regulated by mechanical, chemical, neurohormonal, and immunological factors. Thereafter, plasma concentration of $\mathrm{CNH}$ can be considered as a sensitive index of the perturbation of the homeostatic systems. It is becoming progressively more evident that ANP and BNP can be diversely regulated under certain pathophysiological conditions. Given the important roles of the BNP in both cardiovascular physiology and pathology, the mechanisms that control expression of this hormone merit further investigation.

\section{BIOLOGICAL ACTION OF CNH}

$\mathrm{CNH}$ have powerful physiological effects on hemodynamic, body fluids, and electrolyte homeostasis $(20,33,105,136)$. $\mathrm{CNH}$ share a direct diuretic, natriuretic, and vasodilator effect and an inhibitory action on inflammatory processes of myocardium and smooth muscle cells $(20,33,56,58,98,111,136)$. Moreover, $\mathrm{CNH}$ exert a protective effect on endothelial dysfunction by decreasing shear stress, modulating coagulation and fibrinolysis pathways, and inhibiting platelet activation. According to their anti-inflammatory and antihypertrophic actions, CNH (especially CNP) can also specifically counteract vascular remodeling as well as coronary restenosis postangioplasty processes $(19,108,130,156,159,190)$.

$\mathrm{CNH}$ share an inhibitory action on neurohormonal and immunological systems and on some growth factors $(14,31$, $41,70,72,105,130,167,173,175,185)$. The above-mentioned effects on hemodynamics, body fluid, and electrolyte homeostasis can be explained at least in part by the inhibition of control systems, namely, the sympathetic activation, the renin-angiotensin-aldosterone and/or vasopressin/antidiuretic hormone response, and the endothelins, cytokines, and growth factors release $(14,31,41,70,72,105,130,167,173,175,185)$.

The hormonal action, shared by plasma ANP and BNP, can be enhanced by natriuretic peptides produced locally in target 
tissues. Indeed, endothelial cells synthesize CNP, which in turn exerts a paracrine action on smooth muscle $(19,108,130,156$, 159, 190).

Moreover, renal tubular cells produce urodilatin, another member of the natriuretic peptide family with powerful diuretic and natriuretic properties (176). ANP, BNP, and CNP genes are also expressed in the central nervous system, where they likely function as neurotransmitters and/or neuromodulators $(14,19,41,65,86,173,174)$. This hypothesis is supported, for instance, by the observation that intranasal ANP acts as central nervous inhibitor of the hypothalamus-pituitary-adrenal stress system in humans (126). Finally, coexpression of $\mathrm{CNH}$ and of their receptors was observed in rat thymus cells and macrophages (178, 179), suggesting that $\mathrm{CNH}$ may have immunomodulatory and anti-inflammatory functions in mammals (180).

Finally, several studies suggested a major role for $\mathrm{CNH}$ in the development of certain systems, including skeleton, brain, and vessels $(51,92,137,149,154,183)$. In particular, severe skeletal defects and impaired recovery after vascular and renal injury were observed in $\mathrm{CNH}$ transgenic and knockout mice (183). In addition, $\mathrm{CNH}$ may play a role in the regulation of proliferation, survival, and neurite outgrowth of cultured neuronal and/or glial cells (183).

\section{RESISTANCE TO BIOLOGICAL ACTION OF CNH}

A deficient $\mathrm{CNH}$ response was proposed to explain altered electrolyte and fluid homeostasis occurring in chronic heart failure (23). However, this interpretation was challenged when the CNH system was more carefully investigated in experimental animals and in humans (23). Patients with chronic heart failure show increased $\mathrm{CNH}$ plasma levels compared with healthy subjects (Table 1). This phenomenon has been recently defined as the "endocrine paradox" of the heart (49), characterized by extremely high circulating levels of hormones with powerful natriuretic activity in patients with congestive heart failure who show physical signs of fluid retention and vasoconstriction due to a relatively poor biological activity of the CNH system.

A blunted natriuretic response after pharmacological doses of ANP and BNP has been observed in experimental models and in patients with chronic heart failure, suggesting a resistance to the biological effects of $\mathrm{CNH}$, principally to natriuresis $(18,25,80,140,193)$. This resistance syndrome was also demonstrated by measuring ANP turnover rate with radioactive tracers in patients with heart failure $(23,24)$.

A large number of clinical studies demonstrated that the activation of the neurohormonal system accelerates the left ventricular functional impairment in patients with heart failure $(9,20,22,118)$. Furthermore, drugs that contrast the detrimental effects of the neurohormonal system activation have a key role for the current pharmacological treatment of heart failure. Some of these, such as angiotensin-converting enzyme (ACE) inhibitors, angiotensin-II blockers, $\beta$-blockers, and spironolactone decrease the circulating levels of $\mathrm{CNH}(11,22,88,133)$, "normalize" their kinetics, and increase their biological activity $(23,24)$. In other words, the treatment with this type of pharmacological agent decreases the systemic resistance to the biological effects of CNH $(23,24)$. Indeed, patients with heart failure show a progressive and parallel increase in CNH levels and in some neurohormones and cytokines, which correlates with the severity of the disease. The maximum increase in plasma BNP values (about 45-fold compared with the average value found in healthy subjects) is significantly higher than that observed for neurohormones, cytokines, and even ANP, in heart failure patients (Table 1 and Fig. 3) (39). However, the response of $\mathrm{CNH}$ to increasing levels of disease severity is not linear; it shows a sharp increase in $\mathrm{CNH}$ plasma concentration in the early phase of heart failure (NYHA class I-II patients), followed, with the clinical progression of the disease, by a blunted increase (NYHA class III), and finally by a plateau (NYHA class IV). This time course is more evident, especially the blunted and plateau phases, in the response of ANP compared with BNP (Table 1 and Fig. 3). These data confirm that production and secretion of ANP and BNP are differently regulated and that these two peptide hormones may act as components of two separate systems.

Resistance to the biological action of $\mathrm{CNH}$ can be attributed at least to three different causes. First, circulating $\mathrm{CNH}$ might be, at least in part, inactive. Furthermore, a great fraction of $\mathrm{CNH}$ might be inactivated by plasma and tissue proteases before they bind to specific receptors. These two conditions account for all possible mechanisms acting at the prereceptor level. Second, CNH-specific receptors might be downregulated

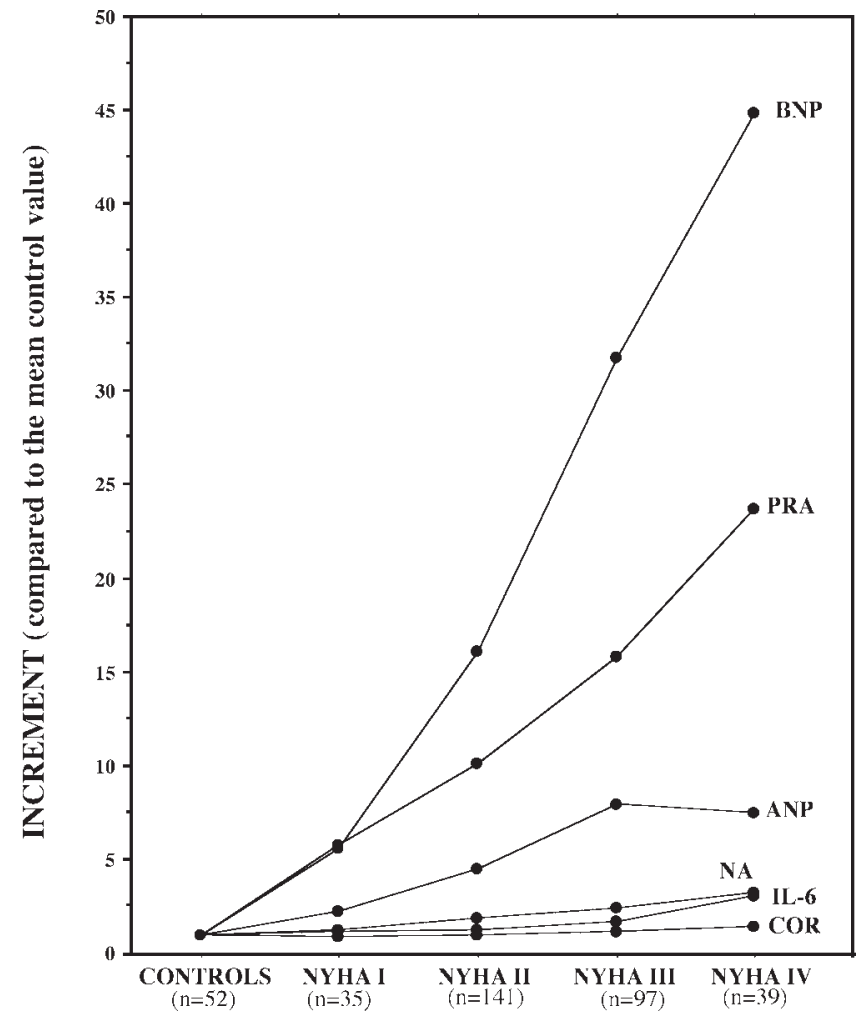

Fig. 3. Mean increases in ANP, BNP, cortisol (COR), IL-6, PRA, and norepinephrin (NE) found in patients with heart failure, divided according to New York Heart Association (NYHA) class. Data obtained from patients were normalized by the mean value found in healthy subjects (controls). Mean (SD) values measured in healthy subjects were the following: ANP, $25.4 \pm 15.8$ ng/l; BNP, $14.3 \pm 20.8 \mathrm{ng} / \mathrm{l} ;$ PRA, $0.34 \pm 0.53 \mathrm{ng} \cdot \mathrm{ml}^{-1} \cdot \mathrm{h}^{-1}$; NE, $344.4 \pm$ $134.0 \mathrm{pg} / \mathrm{ml}$; and cortisol, $165.8 \pm 48.0 \mathrm{ng} / \mathrm{ml}$. For IL-6, the assay detection limit (i.e., $5 \mathrm{pg} / \mathrm{ml}$ ) was taken into account to calculate the increases, because all of the normal subjects studied had values below the sensitivity of the assay. Number of subjects/patients studied for each group is reported in parentheses (data modified from Ref. 39). 
or desensitized. Finally, some mechanisms might act at postreceptor level by counteracting the biological effects of $\mathrm{CNH}$ (Table 3).

Mechanisms acting at prereceptor level. Some peptides, derived in vivo or in vitro from degradation of intact proBNP, are biologically inactive, although they can be measured by immunoassays $(20-22,49)$. Because the circulating levels of intact proBNP and of its derived peptides increase progressively with the severity of heart failure, immunoassays can greatly overestimate the true biological activity of $\mathrm{CNH}$ in patients with severe heart failure (49). Unfortunately, at present, it is not possible to estimate the inaccuracy of $\mathrm{CNH}$ immunoassays because these methods use different, not standardized, antibodies and calibrators leading to very variable results $(20-22,49)$.

$\mathrm{CNH}$ are degraded in vivo and in vitro by several types of proteolytic enzymes, including serine-proteases, peptidyl arginine aldehyde proteases, kallikrein-like proteases, and neutral endopeptidases (NEP) $(8,49,146,147)$. Individual differences in the ability of heart tissue to produce their precursors, or of peripheral tissues to degrade $\mathrm{CNH}$, may help to explain some differences in clinical manifestations among heart failure patients with similar severity of ventricular dysfunction (49).

The pathophysiological relevance of mechanisms acting at the prereceptor level is supported by the clinical effects of drugs sharing an inhibitory action on both NEP and ACE (so called vasopeptidase inhibitors), which may share some beneficial effects in patients with arterial hypertension, heart failure, and/or angina pectoris $(17,28,42,139,166)$. These beneficial effects are mediated by the synergic inhibitory action on ACE and NEP, resulting, respectively, in decreased angiotensin II production and increased circulating levels of $\mathrm{CNH}$ due to a reduction in peptide degradation $(17,28,42,139,166)$. However, a large clinical trial that compared the effects of the vasopeptidase inhibitors omapatrilat to the ACE inhibitor drug enalapril indicated how omapatrilat reduces the risk of death and hospitalization in chronic heart failure but is not more effective than ACE inhibition alone in reducing the risk of a primary clinical event (119).

$\mathrm{CNH}$ are small peptides and therefore are freely filtrated by the kidney. Luminal perfusion with ANP has been shown to reduce sodium efflux from the inner medullar collecting duct, suggesting that this hormone has also luminal sites of action

Table 3. Classification of possibile mechanisms of resistance to biological effects of $\mathrm{CNH}$

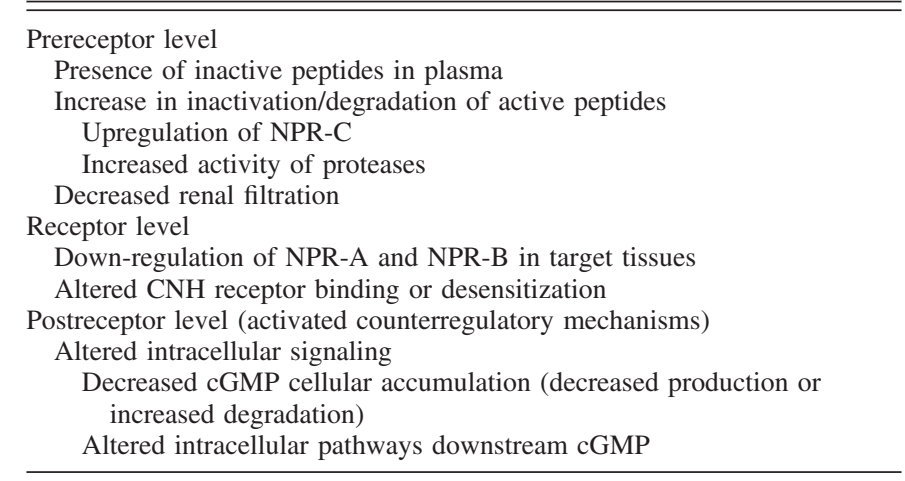

NPR-A, B, C, natriuretic peptide receptors A, B, C.
$(18,150)$. As a consequence, a reduction in the filtration can potentially induce renal hyporesponsiveness to $\mathrm{CNH}$. To date, however, ANP has been detected only on tubular basolateral membranes (18). Thus the mechanisms of $\mathrm{CNH}$ luminal action need to be elucidated before conclusions are drawn about the functional significance of reduced natriuretic peptide filtrations in the renal hyporesponsiveness to ANP and other natriuretic peptides.

Mechanisms acting at receptor level. Several studies suggest that the resistance to biological effects of $\mathrm{CNH}$ in heart failure may be due, in part, to variations in the relative amount of the three different types of natriuretic peptide-specific receptors. In particular, there could be an upregulation of type C-receptors (NPR-C) with a parallel downregulation of type A- and Breceptors (NPR-A and NPR-B) $(6,83,110,168,170)$. NPR-A and NPR-B mediate all known hormonal actions of $\mathrm{CNH}$; therefore, their downregulation should induce a deactivation of the CNH system $(121,122)$. The upregulation of NPR-C receptors that strongly contribute to the clearance of biologically active peptides could further increase the resistance to $\mathrm{CNH}$ in patients with heart failure (8). These findings are well in accordance with kinetic studies in patients with heart failure $(24,64)$. Moreover, a recent report confirmed that the expression of ANP, BNP, and NPR-C receptor were all markedly increased in failing hearts of humans (83). Reversal of cardiomyocyte hypertrophy during left ventricular assist device support was accompanied by normalization of ANP, BNP, and NPR-C mRNA levels and by a significant recovery of responsiveness to ANP (83).

A recent study (40) found that neither NPR-A nor NPR-B were internalized or degraded in response to natriuretic peptide binding in 293T cultured cells, thus suggesting that a downregulation of NRP-A and NPR-B is not the only mechanism for the "inactivation" of $\mathrm{CNH}$ action at the receptor level and that other mechanisms may affect the transduction of $\mathrm{CNH}$ response at the receptor level in some target tissues. Indeed, another well-characterized deactivation mechanism is the process by which an activated receptor is turned off, commonly referred to as "desensitization" (127). Phosphorylation of the intracellular kinase homology domain of NRP-A and NPR-B is required for hormone-dependent activation of the receptor, whereas dephosphorylation at this site causes desensitization (127). Deactivation of $\mathrm{CNH}$ system via desensitization of NRP-A and NPR-B can occur in response to various pathophysiological stimuli (127). Further studies are necessary to clarify what is the most important mechanism of deactivation of the CNH system acting in vivo at the receptor level in patients with heart failure, whether the downregulation (of NPR-A and NPR-B) or the upregulation (of NPR-C) or the desensitization (of NPR-A and NPR-B).

The peripheral resistance to the biological effects of $\mathrm{CNH}$ may play an important role in other clinical conditions besides heart failure. For example, NPR-C is also present on cellular membranes of adipocytes. It was suggested that the increase in NPR-C receptors observed in obese subjects can in turn increase the peripheral degradation of $\mathrm{CNH}$ and consequently blunt the action of the CNH system $(34,143)$. Indeed, recent studies have documented decreased circulating levels of $\mathrm{CNH}$ in obese subjects compared with age and gender-matched controls $(34,106,143,182)$. In these studies, obesity was assessed only based on body mass index. This reduced activity 
of the $\mathrm{CNH}$ system may increase the risk of developing arterial hypertension and other cardiovascular diseases due to the noncontrasted and therefore prevailing effects of the sodiumretentive and vasoconstrictive-opposing mechanisms (34, 106, $143,182)$. However, this hypothesis needs to be confirmed by studies based on accurate and direct measurements of changes in body fat, rather than total, mass.

Finally, recent studies found that NPR-C receptors could be coupled to a $\mathrm{G}$ protein that inhibits cAMP synthesis. These receptors, which are present in great amount especially on the endothelial cell membrane, may mediate some paracrine effects of CNP on vascular tissue $(2,3,38,135)$. Therefore, further studies will be necessary to elucidate the possible role of NPR-C receptors as modulators of $\mathrm{CNH}$ action and/or degradation in peripheral tissues.

Mechanisms acting at postreceptor level. There is evidence to support the hypothesis that the activation of the neuroendocrine system can counteract the biological effects of $\mathrm{CNH}$ even at postreceptor level. However, at present time, the mechanisms responsible for this resistance at postreceptor level are poorly understood. In particular, little is known about potential alterations of the $\mathrm{CNH}$ intracellular signaling pathways in heart failure, and the few published studies have all focused on the second messenger cGMP (18). cGMP levels have been measured and compared with ANP levels. In an early human study, plasma cGMP concentrations increased in proportion to plasma ANP concentrations, suggesting a defect in the signaling pathway downstream cGMP (101). However, renal cGMP production reaches a plateau in more advanced chronic heart failure, despite progressive increase in ANP (101). Similarly, ANP extraction by peripheral vascular bed does not correlate with cGMP production in severe compared with mild chronic heart failure (170). In this pathological condition, renal or peripheral cGMP production may reach a plateau probably because of decreased cGMP generation. However, other mechanisms, such as altered intracellular cGMP turnover, may play a role (18).

Of course, the neuroendocrine system may also indirectly counteract the action of the $\mathrm{CNH}$ system on renal function by exerting antinatriuretic properties. This in turn causes reduced $\mathrm{Na}^{+}$delivery to the collecting tubules, where $\mathrm{CNH}$ exerts its main effects. In fact, the activation of renin-angiotensin-aldosterone axis and of sympathetic nervous and endothelin systems may lead to lower glomerular filtration rate, so limiting $\mathrm{CNH}$ tubular effects with sodium and water retention (184).

Because $\mathrm{CNH}$ and angiotensin II have renal actions at similar vascular and tubular sites, it has been hypothesized that the renin-angiotensin-aldosterone system could counteract the renal $\mathrm{CNH}$ effects, limiting the $\mathrm{CNH}$-induced natriuresis. Moreover, it has been demonstrated in healthy dogs that, at a normal renal perfusion pressure, intrarenal angiotensin II infusion can antagonize ANP-evoked natriuresis (148). Finally, in rats (1) and dogs (177) with aortocaval fistula, 1 wk of ACE inhibition reverses renal unresponsiveness to ANP. On the other hand, sympathetic nerve stimulation provokes afferent and efferent renal arteriolar vasoconstriction and direct $\mathrm{Na}^{+}$ reabsorption throughout the tubule segments, with a predominant action on the ascending limb of the loop of Henle and, to a lesser degree, on the proximal tubule (18). Also arginine vasopressin peptides, which display antidiuretic actions, and endothelins, powerful vasoconstrictor peptides exerting a wide range of effects in the kidney, may both contribute to renal hyporesponsiveness to $\mathrm{CNH}$ in heart failure patients (18). However, further studies are necessary to better clarify the cellular mechanisms responsible for this action.

In summary, several mechanisms occurring at prereceptorial, receptorial, and postreceptorial levels may play a role in the peripheral resistance to the biological effects of $\mathrm{CNH}$ during heart failure. The increased natriuresis and the other beneficial effects induced by drugs inhibiting the action of counterregulatory systems (such as ACE inhibitors, angiotensin II-receptor antagonists, and $\beta$-blocker agents) in patients with heart failure suggest that the overwhelming activation of these systems may be considered the predominant pathophysiological mechanism of $\mathrm{CNH}$ resistance, probably at postreceptorial level. Unfortunately, the effects of the counterregulatory system on downregulation and/or desensitization of natriuretic peptide receptors are presently not well understood.

From a clinical point of view, it is important to underline that the marked resistance to $\mathrm{CNH}$ action may also explain why the administration of $\mathrm{CNH}$ analogues (such as nesiritide) did not seem to have more efficacy than the conventional treatment in patients with decompensated congestive heart failure (146). Indeed, according to the hypothesis of $\mathrm{CNH}$ resistance, an increase in circulating levels of biologically active hormones (obtained by the inhibition of NEP or by nesiritide infusion) can be useful only if there is a significant decrease in the activation of counterregulatory system, as occurs, for example, during concomitant administration of ACE inhibitors, angiotensin II-receptor antagonists, and/or $\beta$-blocker agents. The net effect is a reduced resistance at postreceptor level or an enhanced stimulation of NP-A and NP-B receptors, which induces a reduced resistance at receptor level. A combination of these two beneficial effects is also possible. Finally, the data so far discussed also suggest that monitoring the degree of systemic resistance to the biological effects of $\mathrm{CNH}$ could be clinically useful in the follow-up of patients with heart failure.

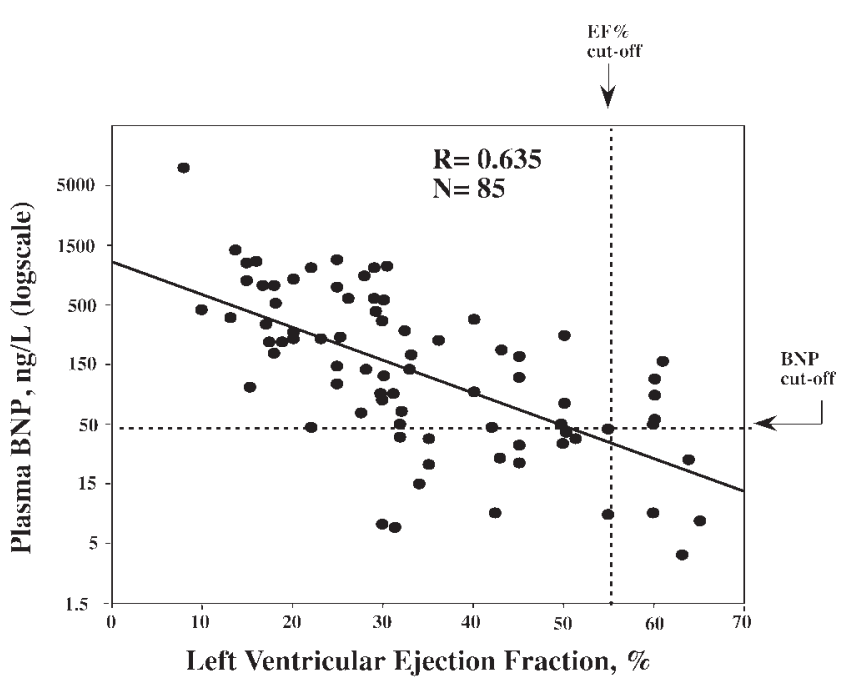

Fig. 4. Close linear relationship between the logarithmic transformation of plasma BNP concentration ( $y$-axis), measured by an immunoradiometric assay method, and left ventricular ejection fraction ( $x$-axis), assessed by nuclear angiography, in patients with cardiovascular diseases (unpublished data from authors' laboratory). 


\section{PATHOPHYSIOLOGICAL AND CLINICAL IMPLICATIONS}

The literature reviewed so far strongly supports the hypothesis that $\mathrm{CNH}$ are active components of the integrated network that includes nervous, endocrine, and immune system. According to this hypothesis, the heart should no longer be considered only as a passive automaton driven by nervous, endocrine, or hemodynamic inputs but as a leading actor on the stage. Therefore, $\mathrm{CNH}$, together with other neurohormonal factors, regulate cardiovascular hemodynamics as well as fluid and electrolyte homeostasis and probably modulate the inflammatory response in some districts, including the cardiovascular. This hypothesis implies that there are two opposing systems in the body: one has sodium-retaining, vasoconstrictive, thrombophylic, proinflammatory, and prohypertrophic actions, whereas the second one promotes natriuresis and vasodilatation and inhibits thrombosis, inflammation, and hypertrophy. $\mathrm{CNH}$ are the main effectors of the latter system and work in concert with NO, some prostaglandins, and other vasodilator peptides. Under physiological conditions, the effects of these two systems are well balanced via feedback mechanisms and result in a beat-to-beat regulation of cardiac output and blood pressure in response to endogenous and exogenous stimuli. In patients with cardiovascular diseases, the action of the first system predominates and constitutes initially a compensatory mechanism that progressively leads to detrimental effects.

The knowledge so far accumulated regarding $\mathrm{CNH}$ suggests that a continuous and intense information exchange flows from the endocrine heart system to nervous and immunological systems and to other organs, including kidney, endocrine glands, liver, adipose tissue, immunocompetent cells, and vice versa. From a pathophysiological point of view, the close link between $\mathrm{CNH}$ system and counterregulatory systems could explain the increase in circulating levels of $\mathrm{CNH}$ in some noncardiac-related clinical conditions. Increased or decreased BNP levels were frequently reported in acute and chronic respiratory diseases $(5,82,90,91,96,112,128,161)$, some endocrine and metabolic diseases $(10,12,15,45,67,79,87$, $117,125,144,153,155)$, liver cirrhosis $(60,89,142)$, renal failure $(103,176)$, acute (septic shock) and chronic inflammatory diseases $(13,16,62,120,158,187,191)$, subarachnoid hemorrhage $(46,84,104)$, and some paraneoplastic syndromes (69, 100, 107). Furthermore, elevated BNP levels reveal an endocrine cardiac response to "stress" that does not necessarily originate from the heart itself. In fact, recent studies reported that plasma BNP concentration is an independent risk factor for mortality (cardiac and/or total) in pulmonary embolism $(81,82$, $161)$ and hypertension (112), renal failure (103, 176), severe sepsis (13, 16), amyloidosis (120), sarcoidosis (191), and diabetes mellitus (12). Increased BNP levels in these noncardiac diseases are a useful indication for the clinician that the heart is under stress.

The interrelationships between $\mathrm{CNH}$ system and proinflammatory cytokines suggest that cardiac hormones play an important role in mechanisms responsible for cardiac and vascular adaptation, maladaptation, and remodeling in response to various physiological and pathological stimuli (48, 99, 141, 181).

Very small changes in some neurohormones and cytokines can produce wider variations in BNP circulating levels (39) (Fig. 3). On the other hand, changes in hemodynamic param- eters and plasma $\mathrm{CNH}$ levels are closely related in patients with cardiovascular diseases (Fig. 4) (20, 22, 27, 36, 93, 109, $116,124)$. However, correlations between plasma CNH levels and parameters such as left ventricular ejection fraction, myocardial mass, and chamber volumes are usually less tight in the general population (large community-based sample, including healthy subjects with or without individuals with asymptomatic myocardial dysfunction) $(71,113,131,172)$. For example, in our laboratory the coefficient of correlation $R$ between left ventricular ejection fraction and BNP in 38 healthy adult subjects without any clinical and echocardiographic evidence of heart failure (mean age $57.3 \mathrm{yr}$, range 35-78 yr) was only 0.068. Furthermore, a recent meta-analysis demonstrated that the diagnostic significance of BNP levels was higher when clinical criteria were used as reference (gold) standard rather than the echocardiographic examination alone (including the criterion of left ventricular ejection fraction of $40 \%$ or less) (37).

These data strongly indicate that the circulating BNP should be better considered as an index of activation of the neuroendocrine system rather than a marker of myocardial dysfunction. The activation or deactivation of the $\mathrm{CNH}$ system is almost always the resultant of one or more physiological or pathological changes. For this reason, the results of $\mathrm{CNH}$ assays must be interpreted by taking into account clinical history and examination, as well as laboratory and instrumental tests. Of course, the great number of pathophysiological mechanisms that can affect the $\mathrm{CNH}$ system renders it sometimes difficult for clinicians to recognize the cause(s) of variations in its activity. On the other hand, $\mathrm{CNH}$ measurements add a complementary information to other instrumental and investigative tests. We believe that $\mathrm{CNH}$ assays should be considered as an intellectual spur for the search of pathophysiological mechanisms that can satisfactorily explain the measured variations in hormone concentrations.

\section{REFERENCES}

1. Abassi Z, Haramati A, Hoffman A, Burnett JC Jr, and Winaver J. Effect of converting enzyme inhibition on renal response to ANF in rats with experimental heart failure. Am J Physiol Regul Integr Comp Physiol 259: R84-R89, 1990.

2. Ahluwalia A, MacAllister RJ, and Hobbs AJ. Vascular actions of natriuretic peptides. Cyclic GMP-dependent and -independent mechanisms. Basic Res Cardiol 99: 83-89, 2004.

3. Anand-Srivastava MB. Natriuretic peptide receptor-C signaling and regulation. Peptides 26: 1044-1059, 2005.

4. Ander AN, Duggirala SK, Drumm JD, and Roth DM. Natriuretic peptide gene expression after beta-adrenergic stimulation in adult mouse cardiac myocytes. DNA Cell Biol 23: 586-591, 2004.

5. Ando T, Ogawa K, Yamaki K, Hara M, and Takagi K. Plasma concentrations of atrial, brain, and C-type natriuretic peptides and endothelin-1 in patients with chronic respiratory diseases. Chest 110: 462 468, 1996.

6. Andreassi MG, Del Ry S, Palmieri C, Clerico A, Biagini A, and Giannessi D. Up-regulation of "clearance" receptors in patients with chronic heart failure: a possible explanation for the resistance to biological effects of cardiac natriuretic hormones. Eur J Heart Fail 3: 407-414, 2001.

7. Baxter GF. Natriuretic peptides and myocardial ischaemia. Basic Res Cardiol 99: 90-93, 2004.

8. Belenky A, Smith A, Zhang B, Lin S, Despres N, Wu ALH, and Bluestein BL. The effect of class-specific protease inhibitors on the stabilization of B-type natriuretic peptide in human plasma. Clin Chim Acta 340: 163-172, 2004.

9. Benedict CR. Neurohormonal aspects of congestive heart failure. Cardiol Clin 12: 9-23, 1994. 
10. Bernstein R, Midtbo K, Urdal P, Morkrid L, Smith G, Muller C, Bjoro T, and Haug E. Serum N-terminal pro-atrial natriuretic factor $1-98$ before and during thyroxine replacement therapy in severe hypothyroidism. Thyroid 7: 415-419, 1997.

11. Bettencourt P. NT-proBNP and BNP: biomarkers for heart failure management. Eur J Heart Fail 6: 359-363, 2004.

12. Bhalla MA, Chiang A, Epshteyn VA, Kazanegra R, Bhalla V, Clopton P, Krishnaswamy P, Morrison LK, Chiu A, Gardetto N, Mudaliar S, Edelman SV, Henry RR, and Maisel AS. Prognostic role of B-type natriuretic peptide levels in patients with type 2 diabetes mellitus. J Am Coll Cardiol 44: 1047-1052, 2004.

13. Brueckmann M, Huhle G, Lang S, Haase KK, Bertsch T, Weiss C, Kaden JJ, Putensen C, Borggrefe M, and Hoffmann U. Prognostic value of plasma $\mathrm{N}$-terminal pro-brain natriuretic peptide in patients with severe sepsis. Circulation 112: 527-534, 2005.

14. Brunner-La Rocca HP, Kaye DM, Woods RL, Hastings J, and Esler MD. Effects of intravenous brain natriuretic peptide on regional sympathetic activity in patients with chronic heart failure compared with healthy control subjects. J Am Coll Cardiol 37: 1221-1227, 2001.

15. Cappuccio FP, Markandu ND, Buckley MG, Sugden AL, Sagnella GA, and MacGregor GA. Raised plasma levels of atrial natriuretic peptides in Addison's disease. J Endocrinol Invest 12: 205-207, 1989.

16. Castillo JR, Zagler A, Carrillo-Jimenez R, and Hennekens CH. Brain natriuretic peptide: a potential marker for mortality in septic shock. Int J Infect Dis 8: 271-274, 2004.

17. Chaitman BR, Ivleva AY, Ujda M, Lenis JH, Toth C, Stieber DM, Reisin LH, Pangerl AM, Friedman JB, and Lawrence JH. Antianginal efficacy of omapatrilat in patients with chronic angina pectoris. Am J Cardiol 95: 1283-1289, 2005.

18. Charloux A, Piquard F, Doutreleau S, Brandenberger G, and Geny B. Mechanisms of renal hyporesponsiveness to ANP in heart failure. Eur J Clin Invest 33: 769-778, 2003.

19. Chen HH and Burnett JC Jr. C-type natriuretic peptide: the endothelial component of the natriuretic peptide system. J Cardiovasc Pharmacol 32, Suppl 3: S22-S28, 1998

20. Clerico A. Pathophysiological and clinical relevance of circulating levels of cardiac natriuretic hormones: is their assay merely a marker of cardiac disease? Clin Chem Lab Med 40: 752-760, 2002.

21. Clerico A, Del Ry S, and Giannessi D. Measurement of natriuretic cardiac hormones (ANP, BNP, and related peptides) in clinical practice: the need for a new generation of immunoassay methods. Clin Chem 46 : $1529-1534,2000$.

22. Clerico A and Emdin M. Diagnostic accuracy and prognostic relevance of the measurement of the cardiac natriuretic peptides: a review. Clin Chem 50: 33-50, 2004.

23. Clerico A and Iervasi G. Alterations in metabolic clearance of atrial natriuretic peptides in heart failure: how do they relate to the resistance to atrial natriuretic peptides? J Card Fail 1: 323-328, 1995.

24. Clerico A, Iervasi G, and Pilo A. Turnover studies on cardiac natriuretic peptides: methodological, pathophysiological and therapeutical considerations. Curr Drug Metab 1: 85-105, 2000.

25. Cody RJ, Atlas SA, Laragh JH, Kubo SH, Covit AB, Ryman KS, Shaknovich A, Pondolfino K, Clark M, Camargo MJ, Scarborough RM, and Lewicki JA. Atrial natriuretic factor in normal subjects and heart failure patients: plasma levels and renal, hormonal and hemodynamic responses to peptide infusion. J Clin Invest 78: 1362-1374, 1986.

26. Cowie MR and Mendez GF. BNP and congestive heart failure. Prog Cardiovasc Dis 44: 293-321, 2002.

27. Dahlstrom U. Can natriuretic peptides be used for the diagnosis of diastolic heart failure? J Eur Hart Fail 6: 281-287, 2004.

28. Dawson A and Struthers AD. Vasopeptidase inhibitors in heart failure. J Renin Angiotensin Aldosterone Syst 3: 156-159, 2002.

29. De Bold AJ, Borenstein HB, Veress AT, and Sonnenberg H. A rapid and important natriuretic response to intravenous injection of atrial myocardial extracts in rats. Life Sci 28: 89-94, 1981.

30. De Bold AJ, Bruneau BG, and Kuroski ML. Mechanical and neuroendocrine regulation of the endocrine heart. Cardiovasc Res 31: 7-18, 1996.

31. De Bold AJ, Ma KK, Zhang Y, de Bold ML, Bensimon M, and Khoshbaten A. The physiological and pathophysiological modulation of the endocrine function of the heart. Can J Physiol Pharmacol 79: 705-714, 2001.
32. De Lemos JA and Morrow DA. Brain natriuretic peptide measurement in acute coronary syndromes: ready for clinical application? Circulation 106: 2868-2870, 2002.

33. De Lemos JA, McGuire DK, and Drazner MH. B-type natriuretic peptide in cardiovascular disease. Lancet 362: 316-322, 2003.

34. Dessi-Fulgheri P, Sarzani R, and Rappelli A. The natriuretic peptide system in obesity-related hypertension: new pathophysiological aspects. J Nephrol 11: 296-269, 1998.

35. Deten A, Volz HC, Briest W, and Zimmer HG. Cardiac cytokine expression is upregulated in the acute phase after myocardial infarction. Experimental studies in rats. Cardiovasc Res 55: 329-340, 2002.

36. Dokainish H, Zoghbi WA, Lakkis NM, Quinones MA, and Nagueh SF. Comparative accuracy of B-type natriuretic peptide and tissue Doppler echocardiography in the diagnosis of congestive heart failure. Am J Cardiol 93: 1130-1135, 2004

37. Doust JA, Glasziou PP, Pietrzak E, and Dobson AJ. A systematic review of the diagnostic accuracy of natriuretic peptides for heart failure. Arch Intern Med 164: 1978-1984, 2004.

38. Drewett JG, Ziegler RJ, and Trachte GJ. Neuromodulatory effects of atrial natriuretic factor are independent of guanylate cyclase in adrenergic neuronal pheochromocytoma cells. J Pharmacol Exp Ther 255: 497-503, 1990.

39. Emdin M, Passino C, Prontera C, Iervasi A, Ripoli A, Masini S, Zucchelli GC, and Clerico A. Cardiac natriuretic hormones, neurohormones, thyroid hormones and cytokines in normal subjects and patients with heart failure. Clin Chem Lab Med 42: 627-636, 2004.

40. Fan D, Bryan PM, Antos LK, Potthaast RJ, and Potter LR. Downregulation does not mediate natriuretic peptide-dependent desensitization of NPR-A or NPR-B: guanylyl cyclase-linked natriuretic peptide receptors do not internalize. J Biol Chem 279: 48513-48519, 2004.

41. Fermepin M, Vatta MS, Presas M, Bianciotti LG, Wolovich TJ, and Fernadez BE. B-type and C-type natriuretic peptides modify norepinephrine uptake in discrete encephalic nuclei of the rat. Cell Mol Neurobiol 20: 763-771, 2000.

42. Floras JS. Vasopeptidase inhibition: a novel approach to cardiovascular therapy. Can J Cardiol 18: 177-182, 2002.

43. Foote RS, Pearlman JD, Siegel AH, and Yeo KT. Detection of exercise-induced ischemia by changes in B-type natriuretic peptides. J Am Coll Cardiol 44: 1980-1987, 2004.

44. Frantz RP, Olson LJ, Grill D, Moualla SK, Nelson SM, Nobrega TP, Hanna RD, Backes RJ, Mookadam F, Heublein D, Bailey KR, and Burnett JC. Carvedilol therapy is associated with a sustained decline in brain natriuretic peptide levels in patients with congestive heart failure. Am Heart J 149: 541-547, 2005.

45. Fujio N, Ohashi M, Nawata H, Kato K, Matsuo H, and Ibayashi H. Cardiovascular, renal and endocrine effects of alpha-human atrial natriuretic peptide in patients with Cushing's syndrome and primary aldosteronism. J Hypertens 7: 653-659, 1989

46. Fukui S, Katoh H, Tsuzuki N, Ishihara S, Otani N, Ooigawa H, Toyooka T, Ohnuki A, Miyazawa T, Nawashiro H, and Shima K. Focal brain edema and natriuretic peptides in patients with subarachnoid hemorrhage. J Clin Neurosci 11: 507-511, 2004.

47. Fukui S, Nawashiro H, Otani N, Ooigawa H, Toyooka T, Tsuzuki N, Katoh H, Ishihara S, Miyazawa T, Ohnuki A, and Shima K. Focal brain edema and natriuretic peptides in patients with subarachnoid hemorrhage. Acta Neurochir Suppl 86: 489-491, 2003.

48. Glembotski CC, Irons CE, Krown KA, Murray SF, Sprenkle AB, and Sei CA. Myocardial alpha-thrombin receptor activation induces hypertrophy and increases atrial natriuretic factor gene expression. J Biol Chem 268: 20646-20652, 1993.

49. Goetze JP. Biochemistry of pro-B-type natriuretic peptide-derived peptides: the endocrine heart revisited. Clin Chem 50: 1503-1510, 2004.

50. Goetze JP, Gore A, Moller CH, Steinbruchel DA, Rehfeld JF, and Nielsen LB. Acute myocardial hypoxia increases BNP gene expression. FASEB J 18: 1929-1930, 2004.

51. Hagiwara H, Sakaguchi H, Itakura M, Yoshimoto T, Furuya M, Tanaka S, and Hirose S. Autocrine regulation of rat chondrocyte proliferation by natriuretic peptide $\mathrm{C}$ and its receptor, natriuretic peptide receptor-B. J Biol Chem 269: 10729-10733, 1994.

52. Hama N, Itoh H, Shirakami G, Nakagawa O, Suga S, Ogawa $Y$, Masuda I, Nakanishi K, Yoshimasa T, Hashimoto Y, Yamaguchi Hori R M, Yasue H, and Nakao K. Rapid ventricular induction of brain natriuretic peptide gene expression in experimental acute myocardial infarction. Circulation 92: 1158-1164, 1995. 
53. Hama J, Nagata S, Takenaka T, Kino H, Kamoi K, Shimada S, Horiuchi M, and Katori R. Atrial natriuretic peptide and antihypertensive action due to beta-blockade in essential hypertensive patients. Angiology 46: 511-516, 1995.

54. Hamanaka I, Saito Y, Nishikimi T, Magaribuchi T, Kamitani S, Kuwahara K, Ishikawa M, Miyamoto Y, Harada M, Ogawa E, Kajiyama N, Takahashi N, Izumi T, Shirakami G, Mori K, Inobe Y, Kishimoto I, Masuda I, Fukuda K, and Nakao K. Effects of cardiotrophin-1 on hemodynamics and endocrine function of the heart. Am J Physiol Heart Circ Physiol 279: H388-H396, 2000.

55. Harada E, Nakagawa O, Yoshimura M, Harada M, Nakagawa M, Mizuno Y, Shimasaki Y, Nakayama M, Yasue H, Kuwahara K, Saito Y, and Nakao K. Effect of interleukin- $1 \beta$ on cardiac hypertrophy and production of natriuretic peptides in rat cardiocyte culture. $\mathrm{J} \mathrm{Mol} \mathrm{Cell}$ Cardiol 31: 1997-2006, 1999.

56. Hardt SE and Sadoshima J. Negative regulators of cardiac hypertrophy (Review). Cardiovasc Res 63: 500-509, 2004.

57. Hasegawa K, Fujiwara H, Doyama K, Mukoyama M, Nakao K, Fujiwara T, Suga S, Mukoyama M, Nakao K, Imura H, and Sasayama S. Ventricular expression of atrial and brain natriuretic peptides in dilated cardiomyopathy. An immunohistocytochemical study of the endomyocardial biopsy specimens using specific monoclonal antibodies. Am J Pathol 142: 107-116, 1993.

58. Hayashi M, Tsutamoto T, Wada A, Maeda K, Mabuchi N, Tsutsui T, Matsui T, Fujii M, Matsumoto T, Yamamoto T, Horie H, Ohnishi M, and Kinoshita M. Intravenous atrial natriuretic peptide prevents left ventricular remodeling in patients with first anterior acute myocardial infarction. J Am Coll Cardiol 37: 1820-1826, 2001.

59. He $\mathbf{Q}$ and LaPointe MC. Interleukin- $1 \beta$ regulation of the human brain natriuretic peptide promoter involves Ras-, Rac-, and p38 kinase-dependent pathways in cardiac myocytes. Hypertension 33: 283-289, 1999.

60. Henriksen JH, Gotze JP, Fuglsang S, Christensen E, Bendtsen F, and Moller S. Increased circulating pro-brain natriuretic peptide (proBNP) and brain natriuretic peptide (BNP) in patients with cirrhosis: relation to cardiovascular dysfunction and severity of disease. Gut 52: 1511-1517, 2003.

61. Hiraoka E, Kawashima S, Takahashi T, Rikitake Y, Hirase T, and Yokoyama M. PI 3-kinase-Akt-p70 S6 kinase in hypertrophic responses to leukemia inhibitory factor in cardiac myocytes. Kobe J Med Sci 49: 25-37, 2003.

62. Hoffmann U, Brueckmann M, Bertsch T, Wiessner M, Liebetrau C, Lang S, Haase KK, Borggrefe M, and Huhle G. Increased plasma levels of NT-proANP and NT-proBNP as markers of cardiac dysfunction in septic patients. Clin Lab 51: 373-379, 2005.

63. Hongo M, Ryoke T, Schoenfeld J, Hunter J, Dalton N, Clark R, Lowe D, Chien K, and Ross J Jr. Effects of growth hormone on cardiac dysfunction and gene expression in genetic murine dilated cardiomyopathy. Basic Res Cardiol 95: 431-441, 2000.

64. Iervasi G, Clerico A, Berti S, Pilo A, Biagini A, Bianchi R, and Donato L. Altered tissue degradation and distribution of atrial natriuretic peptide in patients with idiopathic dilated cardiomyopathy and its relationship with clinical severity of the disease and sodium handling. Circulation 91: 2018-2027, 1995.

65. Imura $\mathbf{H}$, Nakao $\mathbf{K}$, and Itoh $\mathbf{H}$. The natriuretic peptide system in the brain: implications in the central control of cardiovascular and neuroendocrine functions. Front Neuroendocrinol 13: 217-249, 1992.

66. Jamieson JD and Palade GE. Specific granules in atrial muscle cell. J Cell Biol 23: 151-162, 1964.

67. Jensen KT, Carstens J, Ivarsen P, and Pedersen EB. A new, fast and reliable radioimmunoassay of brain natriuretic peptide in human plasma. Reference values in healthy subjects and in patients with different diseases. Scand J Clin Lab Invest 57: 529-540, 1997.

68. Jernberg T, James S, Lindahl B, Johnston N, Stridsberg M, Venge P, and Wallentin L. Natriuretic peptides in unstable coronary artery disease. Eur Heart J 25: 1486-1493, 2004.

69. Johnson BE, Damodaran A, Rushin J, Gross A, Le PT, Chen HC, and Harris RB. Ectopic production and processing of atrial natriuretic peptide in a small cell. Cancer 79: 35-44, 1997.

70. Kapoun AM, Liang F, O'Young G, Damm DL, Quon D, White RT, Munson K, Lam A, Schreiner GF, and Protter AA. B-type natriuretic peptide exerts broad functional opposition to transforming growth factorbeta in primary human cardiac fibroblasts: fibrosis, myofibroblasts conversion, proliferation, and inflammation. Circ Res 94: 453-461, 2004.
71. Kawai K, Hata K, Tanaka K, Kubota Y, Inoue R, Masuda E, Miyazaki T, and Yokoyama M. Attenuation of biological compensatory action of cardiac natriuretic peptide system with aging. Am J Cardiol 93: 719-723, 2004.

72. Kiemer AK, Lehner MD, Hartung T, and Vollmar AM. Inhibition of cyclooxygenase-2 by natriuretic peptides. Endocrinology 143: 846-852, 2002.

73. Kiemer AK, Weber NC, Furst R, Bildner N, Kulhanek-Heinze S, and Vollmar AM. Inhibition of p38 MAPK activation via induction of MKP-1 atrial natriuretic peptide reduces TNF- $\alpha$-induced actin polymerization and endothelial permeability. Circ Res 90: 874-881, 2002.

74. King KL, Winer J, Phillips DM, Quach J, Williams PM, and Mather JP. Phenylephrine, endothelin, prostaglandin F2 alpha and leukemia inhibitory factor induce different cardiac hypertrophy phenotypes in vitro. Endocrine 9: 45-55, 1998.

75. Kinugawa T, Kato M, Ogino K, Igawa O, Hisatome I, Shigemasa C, and Nohara R. Neurohormonal determinants of peak oxygen uptake in patients with chronic heart failure. Jpn Heart J 44: 725-734, 2003.

76. Kinugawa T, Kato M, Ogino K, Osaki S, Tomikura Y, Igawa $\mathbf{O}$, Hisatome I, and Shigemasa C. Interleukin-6 and tumor necrosis factor- $\alpha$ levels increase in response to maximal exercise in patients with chronic heart failure. Int J Cardiol 87: 83-90, 2003.

77. Kirsh B. Electronmicroscopy of the atrium of the heart. I. Guinea pig. Exp Med Surg 14: 99-112, 1956.

78. Knowlton KU, Baracchini E, Ross RS, Harris AN, Henderson SA, Evans SM, Glembotski CC, and Chien KR. Co-regulation of the atrial natriuretic factor and cardiac myosin light chain-2 genes during $\alpha$-adrenergic stimulation of neonatal rat ventricular cells. J Biol Chem 266: 7759-7768, 1991.

79. Kohno M, Horio T, Yasunari K, Yokokawa K, Ikeda M, Kurihara N, Nishizawa Y, Morii H, and Takeda T. Stimulation of brain natriuretic peptide release from heart by thyroid hormone. Metabolism 42: 10591064, 1993

80. Komeichi H, Moreau R, Cailmail S, Gaudin C, and Lebrec D. Blunted natriuresis and abnormal systemic hemodynamic responses to C-type and brain natriuretic peptides in rats with cirrhosis. J Hepatol 22: 319-325, 1995

81. Kruger S, Graf J, Merx MW, Koch KC, Kunz D, Hanrath P, and Janssens U. Brain natriuretic peptide predicts right heart failure in patients with acute pulmonary embolism. Am Heart J 147: 60-65, 2004.

82. Kucher N, Printzen G, and Goldhaber SZ. Prognostic role of brain natriuretic peptide in acute pulmonary embolism. Circulation 107: 25452547,2003

83. Kuhn M, Voss M, Mitko D, Stypmann J, Schmid C, Kawaguchi N, Grabellus F, and Baba HA. Left ventricular assist device support reverses altered cardiac expression and function of natriuretic peptides and receptors in end-stage heart failure. Cardiovasc Res 64: 308-314, 2004.

84. Kurokawa Y, Uede T, Ishiguro M, Honda O, Honmou O, Kato T, and Wanibuchi M. Pathogenesis of hyponatremia following subarachnoid hemorrhage due to ruptured cerebral aneurysm. Surg Neurol 46: 500-507, 1996.

85. Kuroski de Bold ML. Estrogen, natriuretic peptides and the reninangiotensin system. Cardiovasc Res 41: 524-531, 1999.

86. Langub MC Jr, Watson RE Jr, and Herman JP. Distribution of natriuretic peptide precursor mRNAs in the rat brain. J Comp Neurol 356: 183-199, 1995.

87. Lapinski M, Stepniakowski K, Januszewicz A, Wocial B, Chodakowska J, Feltynowski T, and Januszewicz W. Plasma atrial natriuretic peptide concentration in patients with primary aldosteronism. $J$ Hypertens Suppl 9: S260-S261, 1991.

88. Latini R, Masson S, De Angelis N, and Anand I. Role of brain natriuretic peptide in the diagnosis and management of heart failure: current concepts. J Card Fail 8: 288-299, 2002.

89. La Villa G, Riccardi D, Lazzeri C, Casini Raggi V, Dello Sbarba A, Tosti Guerra C, Fronzaroli C, Foschi M, Laffi G, and Gentilini P. Blunted natriuretic response to low-dose brain natriuretic peptide infusion in nonazotemic cirrhotic patients with ascites and avid sodium retention. Hepatology 22: 1745-1750, 1995.

90. Leuchte HH, Holzapfel M, Baumgartner RA, Ding I, Neurohr C, Vogeser M, Kolbe T, Schwaiblmair M, and Behr J. Clinical significance of brain natriuretic peptide in primary pulmonary hypertension. J Am Coll Cardiol 43: 764-770, 2004. 
91. Leuchte HH, Neurohr C, Baumgartner R, Holzapfel M, Giehrl W, Vogeser M, and Behr J. Brain natriuretic peptide and exercise capacity in lung fibrosis and pulmonary hypertension. Am J Respir Crit Care Med 170: 360-365, 2004.

92. Levin ER and Frank HJ. Natriuretic peptides inhibit rat astroglial proliferation: mediation by $\mathrm{C}$ receptor. Am J Physiol Regul Integr Comp Physiol 261: R453-R457, 1991.

93. Logeart D, Saudubray C, Beyne P, Thabut G, Ennezat PV, Chavelas C, Zanker C, Bouvier E, and Solal AC. Comparative values of Doppler echocardiography and B-type natriuretic peptide assay in the etiologic diagnosis of acute dyspnea. J Am Coll Cardiol 40: 1794-1800, 2002.

94. Luchner A, Stevens TL, Borgeson DD, Redfield M, Wei CM, Porter JG, and Burnett JC Jr. Differential atrial and ventricular expression of myocardial BNP during evolution of heart failure. Am J Physiol Heart Circ Physiol 274: H1684-H1689, 1998.

95. Ma KK, Ogawa T, and de Bold AJ. Selective upregulation of cardiac brain natriuretic peptide at the transcriptional and translational levels by pro-inflammatory cytokines and by conditioned medium derived from mixed lymphocyte reactions via p38 MAP kinase. J Mol Cell Cardiol 36: 505-513, 2004

96. Maeder M, Ammann P, Rickli H, and Diethelm M. Elevation of B-type natriuretic peptide levels in acute respiratory distress syndrome. Swiss Med Wkly 133: 515-518, 2003.

97. Maffei S, Del Ry S, Prontera C, and Clerico A. Increase in circulating levels of cardiac natriuretic peptides after hormone replacement therapy in postmenopausal women. Clin Sci (Colch) 101: 447-453, 2001.

98. Magga J, Puhakka M, Hietakorpi S, Punnonen K, Uusimaa P, Risteli J, Vuolteenaho O, Ruskoaho H, and Peuhkurinen K. Atrial natriuretic peptide, B-type natriuretic peptide, and serum collagen markers after acute myocardial infarction. J Appl Physiol 96: 1306-1311, 2004.

99. Mann DL. Stress-activated cytokines and the heart: from adaptation to maladaptation. Аппи Rev Physiol 65: 81-101, 2003.

100. Marchioli CC and Graziano SL. Paraneoplastic syndromes associated with small cell lung cancer. Chest Surg Clin N Am 7: 65-80, 1997.

101. Margulies KB, Heublein DM, Perrella MA, and Burnett JC Jr. ANF-mediated renal cGMP generation in congestive heart failure. Am J Physiol Renal Fluid Electrolyte Physiol 260: F562-F568, 1991.

102. Marie JP, Guillemont H, and Hatt PY. Le degré de granulation des cardiocytes auriculaires. Etude planimétriques au cours de differents apports d'eau et de sodium chez le rat. Pathol Biol (Paris) 24: 549-554, 1976.

103. McCullough PA, Kuncheria J, and Mathur VS. Diagnostic and therapeutic utility of B-type natriuretic peptide in patients with renal insufficiency and decompensated heart failure. Rev Cardiovasc Med 5: $16-25,2004$

104. McGirt MJ, Blessing R, Nimjee SM, Friedman AH, Alexander MJ, Laskowitz DT, and Lynch JR. Correlation of serum brain natriuretic peptide with hyponatremia and delayed ischemic neurological deficits after subarachnoid hemorrhage. Neurosurgery 54: 1369-1373, 2004.

105. McGrath MF and de Bold AJ. Determinants of natriuretic peptide gene expression. Peptides 26: 933-943, 2005.

106. Mehra MR, Uber PA, Park MH, Scott RL, Ventura HO, Harris BC, and Frohlich ED. Obesity and suppressed B-type natriuretic peptide levels in heart failure. J Am Coll Cardiol 43: 1590-1595, 2004.

107. Mimura Y, Kanauchi H, Ogawa T, and Oohara T. Resistance to natriuresis in patients with peritonitis carcinomatosa. Horm Metab Res 28: 183-186, 1996.

108. Morishige K, Shimokawa H, Yamawaki T, Miyata K, Eto Y, Kandabashi T, Yogo K, Higo T, Egashira K, Ueno H, and Takeshita $A$. Local adenovirus-mediated transfer of C-type natriuretic peptide suppresses vascular remodeling in porcine coronary arteries in vivo. $J$ Am Coll Cardiol 35: 1040-1047, 2000.

109. Mottram PM, Haluska BA, and Marwick TH. Response of B-type natriuretic peptide to exercise in hypertensive patients with suspected diastolic heart failure: correlation with cardiac function, hemodynamics, and workload. Am Heart J 148: 365-370, 2004.

110. Mukaddam-Daher S, Tremblay J, Fujio N, Koch C, Jankowski M, Quillen EW Jr, and Gutkowska J. Alteration of lung atrial natriuretic peptide receptors in genetic cardiomyopathy. Am J Physiol Lung Cell Mol Physiol 271: L38-L145, 1996.

111. Nagaya N, Nishikimi T, Goto Y, Miyao Y, Kobayashi Y, Morii I, Daikoku S, Matsumoto T, Miyazaki S, Matsuoka H, Takishita S, Kangawa K, Matsuo H, and Nonogi H. Plasma brain natriuretic peptide is a biochemical marker for the prediction of progressive ventricular remodeling after acute myocardial infarction. Am Heart J 135: 21-28, 1998.

112. Nagaya N, Nishikimi T, Uematsu M, Satoh T, Kyotani S, Sakamaki F, Kakishita M, Fukushima K, Okano Y, Nakanishi N, Miyatake K, and Kangawa K. Plasma brain natriuretic peptide as a prognostic indicator in patients with primary pulmonary hypertension. Circulation 102: 865-870, 2000.

113. Nakamura M, Endo H, Nasu M, Arakawa N, Segawa T, and Hiramori K. Value of plasma B type natriuretic peptide measurement for heart disease screening in a Japanese population. Heart 87: 131-135, 2002.

114. Nakaoka H, Kitahara Y, Amano M, Imataka K, Fujii J, Ishibashi M, and Yamaji T. Effect of beta-adrenergic receptor blockade on atrial natriuretic peptide in essential hypertension. Hypertension 10: 221-225, 1987.

115. Nicolau N, Butur G, and Laky D. Electronmicroscopic observations regarding the presence of natriuretic granules in the ventricle of patients with cardiopathies. Rom J Morphol Embryol 43: 119-137, 1997.

116. Ogawa K, Oida A, Sugimura H, Kaneko N, Nogi N, Hasumi M, Numao T, Nagao I, and Mori S. Clinical significance of blood brain natriuretic peptide levels measurement in the detection of heart disease in untreated outpatients. Comparison of electrocardiography, chest radiography and echocardiography. Circ J 66: 122-126, 2002.

117. Opocher G, Rocco S, Carpene G, Pedini F, Scarante M, Milani R, Boscaro M, and Mantero F. Atrial natriuretic peptide in Cushing's disease. J Endocrinol Invest 13: 133-137, 1990.

118. Packer M. The neurohormonal hypothesis: a theory to explain the mechanisms of disease progression in heart failure. $\mathrm{J} \mathrm{Am} \mathrm{Coll} \mathrm{Cardiol}$ 20: 248-254, 1992

119. Packer M, Califf RM, Konstam MA, Krum H, McMurray JJ, Rouleau JL, and Swedberg K. Comparison of omapatrilat and enalapril in patients with chronic heart failure: the Omapatrilat Versus Enalapril Randomized Trial of Utility in Reducing Events (OVERTURE). Circulation 106: 920-926, 2002.

120. Palladini G, Campana C, Klersy C, Balduini A, Vadacca G, Perfetti V, Perlini S, Obici L, Ascari E, d'Eril GM, Moratti R, and Merlini G. Serum N-terminal pro-brain natriuretic peptide is a sensitive marker of myocardial dysfunction in AL amyloidosis. Circulation 107: 2440 2445, 2003.

121. Pandey KN. Biology of natriuretic peptides and their receptors. Peptides 26: 901-932, 2005.

122. Pandey KN. Internalization and trafficking of guanylyl cyclase/natriuretic peptide receptor-A. Peptides 26: 985-1000, 2005.

123. Papadopoulos CL, Kokkas B, Kotridis P, Karamouzis M, Haldoupi M, Platis A, Dadoush G, and Kanonidis I. Effect of the beta 1-blocker/ beta 2-agonist celiprolol on atrial natriuretic peptide plasma levels in hypertensive patients. Cardiovasc Drugs Ther 12: 345-346, 1998.

124. Park MH, Uber PA, Scott RL, and Mehra MR. B-type natriuretic peptide in heart transplantation: an important marker of allograft performance. Heart Fail Rev 8: 359-363, 2003

125. Parlapiano C, Campana E, Alessandri N, Rota C, Sellini M, Vecci E, Tonnarini G, Borgia MC, and Negri M. Plasma atrial natriuretic hormone in hyperthyroidism. Endocr Res 24: 105-112, 1998.

126. Perras B, Schultes B, Behn B, Dodt C, Born J, and Fehm HL. Intranasal atrial natriuretic peptide acts as central nervous inhibitor of the hypothalamo-pituitary-adrenal stress system in humans. J Clin Endocrinol Metab 89: 4642-4648, 2004.

127. Potthast R and Potter LR. Phosphorylation-dependent regulation of the guanylyl cyclase-linked natriuretic peptide receptors. Peptides 26: 10011008,2005

128. Pruszczyk P, Kostrubiec M, Bochowicz A, Styczynski G, Szulc M, Kurzyna M, Fijalkowska A, Kuch-Wocial A, Chlewicka I, and Torbicki A. N-terminal pro-brain natriuretic peptide in patients with acute pulmonary embolism. Eur Respir J 22: 649-653, 2003.

129. Qi W, Kjekshus J, and Hall C. Differential responses of plasma atrial and brain natriuretic peptides to acute alteration in atrial pressure in pigs. Scand J Clin Lab Invest 60: 55-63, 2000.

130. Qian JY, Haruno A, Asada Y, Nishida T, Saito Y, Matsuda T, and Ueno H. Local expression of C-type natriuretic peptide suppresses inflammation, eliminates shear stress-induced thrombosis, and prevents neointima formation through enhanced nitric oxide production in rabbit injured carotid arteries. Circ Res 91: 1063-1069, 2002. 
131. Redfield MM, Rodeheffer RJ, Jacobsen SJ, Mahoney DW, Bailey KR, and Burnett JC Jr. Plasma brain natriuretic peptide concentrations: impact of age and gender. J Am Coll Cardiol 40: 976-982, 2002.

132. Richards AM, Lainchbury JG, Nicholls MG, Cameron AV, and Yandle TG. Dendroaspis natriuretic peptide: endogenous or dubious? Lancet 359: 5-6, 2002.

133. Richards AM, Lainchbury JG, Nicholls MG, Troughton RW, and Yandle TG. BNP in hormone-guided treatment of heart failure. Trends Endocrinol Metab 13: 151-155, 2002.

134. Richards M and Troughton RW. NT-proBNP in heart failure: therapy decisions and monitoring. Eur J Heart Fail 6: 351-354, 2004

135. Riegger GA, Elsner D, Kromer EP, Daffner C, Forssmann WG, Muders F, Pascher EW, and Kochsiek K. Atrial natriuretic peptide in congestive heart failure in the dog: plasma levels, cyclic guanosine monophosphate, ultrastructure of atrial myoendocrine cells, and hemodynamic, hormonal, and renal effects. Circulation 77: 398-406, 1988.

136. Ruskoaho H. Cardiac hormones as diagnostic tools in heart failure. Endocr Rev 24: 341-356, 2003.

137. Ryan MC and Gundlach AL. Ontogenic expression of natriuretic peptide mRNAs in postnatal rat brain: implications for development? Brain Res Dev Brain Res 105: 251-268, 1998.

138. Sabatine MS, Morrow DA, de Lemos JA, Omland T, Desai MY, Tanasijevic M, and Hall C, McCabe $\mathbf{C H}$, and Braunwald E. Acute changes in circulating natriuretic peptide levels in relation to myocardial ischemia. J Am Coll Cardiol 44: 1988-1995, 2004.

139. Sagnella GA. Vasopeptidase inhibitors. J Renin Angiotensin Aldosterone Syst 3: 90-95, 2002

140. Saito Y, Nakao K, Nishimura K, Sugawara A, Okumura K, Obata K, Sonoda R, Ban T, Yasue H, and Imura H. Clinical application of atrial natriuretic polypeptide in patients with congestive heart failure: beneficial effects on left ventricular function. Circulation 76: 115-124, 1987.

141. Sakata Y, Yamamoto K, Masuyama T, Mano T, Nishikawa N, Kuzuya T, Miwa T, and Hori M. Ventricular production of natriuretic peptides and ventricular structural remodelling in hypertensive heart failure. J Hypertens 19: 1905-1509, 2001.

142. Salo J, Jimenez W, Kuhn M, Gines A, Gines P, Fernandez-Esparrach G, Angeli P, Claria J, Bataller R, Arroyo V, Forssmann WG, and Rodes J. Urinary excretion of urodilatin in patients with cirrhosis. Hepatology 24: 1428-1432, 1996.

143. Sarzani R, Strazzullo P, Salvi F, Iacone R, Pietrucci F, Siani A, Barba G, Gerardi MC, Dessi-Fulgheri P, and Rappelli A. Natriuretic peptide clearance receptor alleles and susceptibility to abdominal adiposity. Obes Res 12: 351-356, 2004

144. Schultz M, Faber J, Kistorp C, Jarlov A, Pedersen F, Wiinberg N, and Hildebrandt P. N-terminal-pro-B-type natriuretic peptide (NT-pro$\mathrm{BNP}$ ) in different thyroid function states. Clin Endocrinol (Oxf) 60: 54-59, 2004

145. Shen W, Xu X, Ochoa M, Zeballos GA, Stewart JM, and Hintze TH. Contribution of the ventricles and the atrial appendages to the elevation of plasma atrial natriuretic factor (ANF) during pacing-induced heart failure in conscious dogs. Basic Res Cardiol 91: 319-328, 1996.

146. Shimizu H, Masuta K, Aono K, Asada H, Sasakura K, Tamaki M, Sugita K, and Yamada K. Molecular forms of human brain natriuretic peptide in plasma. Clin Chim Acta 316: 129-135, 2002.

147. Shimizu H, Masuta K, Asada H, Sugita K, and Sairenji T. Characterization of molecular forms of probrain natriuretic peptide in human plasma. Clin Chim Acta 334: 233-239, 2003.

148. Showalter CJ, Zimmerman RS, Schwab TR, Edwards BS, Opgenorth TJ, and Burnett JC Jr. Renal response to atrial natriuretic factor is modulated by intrarenal angiotensin II. Am J Physiol Regul Integr Comp Physiol 254: R453-R456, 1988.

149. Simpson PJ, Miller I, Moon C, Hanlon AL, Liebl DJ, and Ronnett GV. Atrial natriuretic peptide type C induces a cell-cycle switch from proliferation to differentiation in brainderived neurotrophic factor- or nerve growth factor-primed olfactory receptor neurons. J Neurosci 22 : 5536-5551, 2002.

150. Sonnenberg H, Honrath $\mathbf{U}$, and Wilson DR. In vivo microperfusion of inner medullary collecting duct in rats: effect of amiloride and ANF. Am J Physiol Renal Fluid Electrolyte Physiol 259: F222-F226, 1990.

151. Sprenkle AB, Murray SF, and Glemboski CC. Involvement of multiple cis elements in basal-and $\alpha$-adrenergic agonist-inducible atrial natriuretic factor transcription. Roles for serum response elements and an SP-1-like element. Circ Res 77: 1060-1069, 1995.
152. Stewart JM, Wang J, Zeballos GA, Ochoa M, Schustek M, and Hintze TH. Role of tachycardia and V wave wall stress in the release of ANF during volume loading. Am J Physiol Heart Circ Physiol 264: H217-H223, 1993.

153. Straub RH, Hall C, Kramer BK, Elbracht R, Palitzsch KD, Lang B, and Scholmerich J. Atrial natriuretic factor and digoxin-like immunoreactive factor in diabetic patients: their interrelation and the influence of the autonomic nervous system. J Clin Endocrinol Metab 81: 3385-3389, 1996.

154. Suda M, Ogawa Y, Tanaka K, Tamura N, Yasoda A, Takigawa Uehira MT, Nishimoto H, Itoh H, Saito Y, Shiota K, and Nakao K. Skeletal overgrowth in transgenic mice that overexpress brain natriuretic peptide. Proc Natl Acad Sci USA 95: 2337-2342, 1998.

155. Sugawara A, Nakao K, Itoh H, Yamada T, Saito Y, Mukoyama M, Arai H, Hosoda K, Shirakami G, and Morii N. Cosecretion of peptides derived from gamma-human atrial natriuretic polypeptide in normal volunteers and patients with essential hypertension and adrenal disorders. J Hypertens Suppl 6: S327-S329, 1988.

156. Takahashi N, Saito Y, Kuwahara K, Harada M, Kishimoto I, Ogawa Y, Kawakami R, Nakagawa Y, Nakanishi M, and Nakao K. Angiotensin II-induced ventricular hypertrophy and extracellular signal-regulated kinase activation are suppressed in mice overexpressing brain natriuretic peptide in circulation. Hypertens Res 26: 847-853, 2003.

157. Takeda Y, Fukutomi T, Suzuki S, Yamamoto K, Ogata M, Kondo H, Sugiura M, Shigeyama J, and Itoh M. Effects of carvedilol on plasma B-type natriuretic peptide concentration and symptoms in patients with heart failure and preserved ejection fraction. Am J Cardiol 94: 448-453, 2004.

158. Takemura G, Takatsu Y, Doyama K, Itoh H, Saito Y, Koshiji M, Ando F, Fujiwara T, Nakao K, and Fujiwara H. Expression of atrial and brain natriuretic peptides and their genes in hearts of patients with cardiac amyloidosis. J Am Coll Cardiol 31: 254-265, 1998.

159. Takeuchi H, Ohmori K, Kondo I, Oshita A, Shinomiya K, Yu Y, Takagi Y, Mizushige K, Kangawa K, and Kohno M. Potentiation of C-type natriuretic peptide with ultrasound and microbubbles to prevent neointimal formation after vascular injury in rats. Cardiovasc Res 58: 231-238, 2003

160. Tanaka T, Kanda T, Takahashi T, Saegusa S, Moriya J, and Kurabayashi M. Interleukin-6-induced reciprocal expression of SERCA and natriuretic peptides mRNA in cultured rat ventricular myocytes. $J$ Int Med Res 32: 57-61, 2004.

161. Ten Wolde M, Tulevski II, Mulder JW, Sohne M, Boomsma F, Mulder BJ, and Buller HR. Brain natriuretic peptide as a predictor of adverse outcome in patients with pulmonary embolism. Circulation 107: 2082-2084, 2003.

162. Thuerauf DJ, Arnold ND, Zechner D, Hanford DS, DeMartin KM, McDonough PM, Prywes R, and Glembotski CC. p38 Mitogenactivated protein kinase mediates the transcriptional induction of the atrial natriuretic factor gene through a serum response element. A potential role for the transcription factor ATF6. J Biol Chem 273: 20636-20643, 1998.

163. Tokudome T, Horio T, Yoshihara F, Suga S, Kawano Y, Kohno M, and Kangawa K. Direct effects of high glucose and insulin on protein synthesis in cultured cardiac myocytes and DNA and collagen synthesis in cardiac fibroblasts. Metabolism 53: 710-715, 2004.

164. Topol EJ. Nesiritide-not verified. N Engl J Med 353: 113-116, 2005.

165. Toth M, Vuorinen KH, Vuolteenaho O, Hassinen IE, Uusimaa PA, Leppaluoto J, and Ruskoaho H. Hypoxia stimulates release of ANP and BNP from perfused rat ventricular myocardium. Am J Physiol Heart Circ Physiol 266: H1572-H1580, 1994.

166. Trindade PT and Rouleau JL. Vasopeptidase inhibitors: potential role in the treatment of heart failure. Heart Fail Monit 2: 2-7, 2001.

167. Tsukagoshi H, Shimizu Y, Kawata T, Hisada T, Shimizu Y, Iwamae S, Ishizuka T, Iizuka K, Dobashi K, and Mori M. Atrial natriuretic peptide inhibits tumor necrosis factor-alpha production by interferongamma-activated macrophages via suppression of p38 mitogen-activated protein kinase and nuclear factor-kappa B activation. Regul Pept 99: $21-29,2001$.

168. Tsunoda K, Mendelsoohn FAO, Sexton PM, Chai SY, Hodsman GP, and Johnston CI. Decreased atrial natriuretic peptide binding in renal medulla in rats with chronic heart failure. Circ Res 62: 155-161, 1988.

169. Tsuruda T, Boerrigter G, Huntley BK, Noser JA, Catalotti A, Costello-Boerrigter LC, Chen HH, and Burnett JC Jr. Brain natri- 
uretic peptide is produced in cardiac fibroblasts and induces matrix metalloproteinases. Circ Res 91: 1127-1134, 2002.

170. Tsutamoto T, Kanamory T, Morigami N, Sugimoto Y, Yamaoka O, and Kinoshita M. Possibility of downregulation of atrial natriuretic peptide receptor coupled to guanylate cyclase in peripheral vascular beds of patients with chronic severe heart failure. Circulation 87: 70-75, 1993.

171. Van den Meiracker AH, Lameris TW, van de Ven LL, and Boomsma F. Increased plasma concentration of natriuretic peptides by selective beta1-blocker bisoprolol. J Cardiovasc Pharmacol 42: 462-468, 2003.

172. Vasan RS, Benjamin EJ, Larson MG, Leip EP, Wang TJ, Wilson PW, and Levy D. Plasma natriuretic peptides for community screening for left ventricular hypertrophy and systolic dysfunction: the Framingham heart study. JAMA 288: 1252-1259, 2002.

173. Vatta MS, Presas M, Bianciotti LG, Zarrabeita V, and Fernadez BE. $\mathrm{B}$ and $\mathrm{C}$ types natriuretic peptides modulate norepinephrine uptake and release in the rat hypothalamus. Regul Pept 16: 175-184, 1996.

174. Vatta MS, Presas M, Bianciotti LG, Rodriguez-Fermepin M, Ambros R, and Fernadez BE. B and C types natriuretic peptides modify norepinephrine uptake and release in the rat adrenal medulla. Peptides 18: 1483-1489, 1997.

175. Ventura RR, Gomes DA, Reis WL, Elias LL, Castro M, Valenca MM, Carnio EC, Rettori V, McCann SM, and Antunes-Rodrigues J. Nitrergic modulation of vasopressin, oxytocin and atrial natriuretic peptide secretion in response to sodium intake and hypertonic blood volume expansion. Braz J Med Biol Res 35: 1101-1109, 2002.

176. Vesely DL. Natriuretic peptides and acute renal failure. Am J Physiol Renal Physiol 285: F167-F177, 2003.

177. Villarreal D, Freeman RH, and Johnson RA. Captopril enhances renal responsiveness to ANF in dogs with compensated high-output heart failure. Am J Physiol Regul Integr Comp Physiol 262: R509-R516, 1992.

178. Vollmar AM and Schultz R. Expression and differential regulation of natriuretic peptides in mouse macrophages. J Clin Invest 95: 2442-2450, 1995.

179. Vollmar AM, Wolf R, and Schulz R. Co-expression of the natriuretic peptides (ANP, BNP, CNP) and their receptors in normal and acutely involuted rat thymus. J Neuroimmunol 57: 117-127, 1995.

180. Vollmar AM and Kiemer AK. Immunomodulatory and cytoprotective function of atrial natriuretic peptide. Crit Rev Immunol 21: 473-485, 2001

181. Walther T, Klostermann K, Hering-Walther S, Schultheiss HP, Tschope C, and Stepan H. Fibrosis rather than blood pressure determines cardiac BNP expression in mice. Regul Pept 116: 95-100, 2003.
182. Wang TJ, Larson MG, Levy D, Benjamin EJ, Leip EP, Wilson PW, and Vasan RS. Impact of obesity on plasma natriuretic peptide levels. Circulation 109: 594-600, 2004.

183. Waschek JA. Developmental actions of natriuretic peptides in the brain and skeleton. Cell Mol Life Sci 61: 2332-2342, 2004.

184. Watkins L Jr, Burton JA, Haber E, Cant JR, Smith FW, and Barger AC. The renin angiotensin-aldosterone system in congestive failure in conscious dogs. J Clin Invest 57: 1606-1617, 1976.

185. Weber NC, Blumenthal SB, Hartung T, Vollmar AM, and Kiemer AK. ANP inhibits TNF-alpha-induced endothelial MCP-1 expressioninvolvement of p38 MAPK and MKP-1. J Leukoc Biol 74: 932-941, 2003

186. Williams SG, Ng LL, O'Brien RJ, Taylor S, Li YF, and Tan LB. Comparison of plasma N-brain natriuretic peptide, peak oxygen consumption, and left ventricular ejection fraction for severity of chronic heart failure. Am J Cardiol 93: 1560-1561, 2004.

187. Witthaut R, Busch C, Fraunberger P, Walli A, Seidel D, Pilz G, Stuttmann R, Speichermann N, Verner L, and Werdan K. Plasma atrial natriuretic peptide and brain natriuretic peptide are increased in septic shock: impact of interleukin-6 and sepsis-associated left ventricular dysfunction. Intensive Care Med 29: 1696-1702, 2003.

188. Woodard GE, Rosado JA, and Brown J. Expression and control of C-type natriuretic peptide in rat vascular smooth muscle cells. Am J Physiol Regul Integr Comp Physiol 282: R156-R165, 2002.

189. Wu X, Seino Y, Ogura H, Fukuma N, Katoh T, and Takano T. Plasma natriuretic peptide levels and daily physical activity in patients with pacemaker implantation. Jpn Heart J 42: 471-482, 2001.

190. Yasuda S, Kanna M, Sakuragi S, Kojima S, Nakayama Y, Miyazaki S, Matsuda T, Kangawa K, and Nonogi $\mathbf{H}$. Local delivery of single low-dose of C-type natriuretic peptide, an endogenous vascular modulator, inhibits neointimal hyperplasia in a balloon-injured rabbit iliac artery model. J Cardiovasc Pharmacol 39: 784-788, 2002.

191. Yasutake H, Seino Y, Kashiwagi M, Honma H, Matsuzaki T, and Takano T. Detection of cardiac sarcoidosis using cardiac markers and myocardial integrated backscatter. Int J Cardiol 102: 259-268, 2005.

192. Yoshizawa A, Yoshikawa T, Nakamura I, Satoh T, Moritani K, Suzuki M, Baba A, Iwanaga S, Mitamura H, and Ogawa S. Brain natriuretic peptide response is heterogeneous during beta-blocker therapy for congestive heart failure. J Card Fail 10: 310-315, 2004.

193. Zeidel ML. Physiological responses to natriuretic hormones. In: Handbook of Physiology. The Endocrine System. Endocrine Regulation of Water and Electrolyte Balance. Bethesda, MD: Am. Physiol. Soc., 2000, sect. 7 , vol. III, chapt. 11 , p. $410-435$. 